\title{
Genomic Signals of Adaptation towards Mutualism and Sociality in Two Ambrosia Beetle Complexes
}

\author{
Jazmín Blaz ${ }^{1}$, Josué Barrera-Redondo ${ }^{2}$, Mirna Vázquez-Rosas-Landa ${ }^{1}$, Anahí Canedo-Téxon ${ }^{1}$, \\ Eneas Aguirre von Wobeser ${ }^{3}{ }^{-}$, Daniel Carrillo ${ }^{4}$, Richard Stouthamer ${ }^{5}$, Akif Eskalen ${ }^{6}$, \\ Emanuel Villafán ${ }^{1}$, Alexandro Alonso-Sánchez ${ }^{1}$, Araceli Lamelas ${ }^{1}{ }^{1}$, \\ Luis Arturo Ibarra-Juarez ${ }^{1,7}\left(\mathbb{0}\right.$, Claudia Anahí Pérez-Torres ${ }^{1,7}$ and Enrique Ibarra-Laclette ${ }^{1, *}$ (i) \\ 1 Red de Estudios Moleculares Avanzados, Instituto de Ecología A.C, Xalapa, Veracruz 91070, Mexico; \\ jazminblax@gmail.com (J.B.); mirnavrl@gmail.com (M.V.-R.-L.); \\ anahi.canedo@posgrado.ecologia.edu.mx (A.C.-T.); emanuel.villafan@inecol.mx (E.V.); \\ alexandro.alonso@inecol.mx (A.A.-S.); araceli.lamelas@inecol.mx (A.L.); luis.ibarra@inecol.mx (L.A.I.-J.); \\ claudia.perez@inecol.mx (C.A.P.-T.) \\ 2 Departamento de Ecología Evolutiva, Instituto de Ecología, Universidad Nacional Autónoma de México, \\ Ciudad de México 04500, Mexico; josue_barrera@comunidad.unam.mx \\ 3 Cátedras CONACyT/Centro de Investigación en Alimentación y Desarrollo, Hermosillo 83304, Mexico; \\ eneas.aguirre@ciad.mx \\ 4 Tropical Research and Education Center, University of Florida, Homestead, FL 33031, USA; dancar@ufl.edu \\ 5 Department of Plant Pathology, University of California-Riverside, Riverside, CA 92521, USA; \\ richards@ucr.edu \\ 6 Department of Plant Pathology, University of California, Davis, CA 95616-8751, USA; aeskalen@ucdavis.edu \\ 7 Cátedras CONACyT/Instituto de Ecología A.C., Xalapa, Veracruz 91070, Mexico \\ * Correspondence: enrique.ibarra@inecol.mx; Tel.: +52-(228)-842-18-00
}

Received: 14 October 2018; Accepted: 20 December 2018; Published: 22 December 2018

\begin{abstract}
Mutualistic symbiosis and eusociality have developed through gradual evolutionary processes at different times in specific lineages. Like some species of termites and ants, ambrosia beetles have independently evolved a mutualistic nutritional symbiosis with fungi, which has been associated with the evolution of complex social behaviors in some members of this group. We sequenced the transcriptomes of two ambrosia complexes (Euwallacea sp. near fornicatus-Fusarium euwallaceae and Xyleborus glabratus-Raffaelea lauricola) to find evolutionary signatures associated with mutualism and behavior evolution. We identified signatures of positive selection in genes related to nutrient homeostasis; regulation of gene expression; development and function of the nervous system, which may be involved in diet specialization; behavioral changes; and social evolution in this lineage. Finally, we found convergent changes in evolutionary rates of proteins across lineages with phylogenetically independent origins of sociality and mutualism, suggesting a constrained evolution of conserved genes in social species, and an evolutionary rate acceleration related to changes in selective pressures in mutualistic lineages.
\end{abstract}

Keywords: mutualism; sociality evolution; ambrosia beetle complexes; polyphagous shot hole borer; redbay ambrosia beetle

\section{Introduction}

By definition, mutualistic symbiosis increases the fitness of all participant partners, at least in terms of inclusive fitness [1]. Therefore, mutualistic lineages are interdependent, and natural selection drives their coevolution [2]. Elucidating how these mutualistic partnerships influence genes and 
genomes is essential to understanding complex ecological interactions in an evolutionary context, and is thus a fundamental aim of life sciences.

One of the most notable cases of mutualistic symbiosis in nature is the farming of fungi by several insect groups [2]. Nutritional mutualistic symbiosis with fungi has evolved over tens of millions of years in Attini ants, Macrotermitinae termites, and Scolytinae or Platypodinae ambrosia beetles, enabling these organisms to colonize new ecological niches [1,2]. Of these fungus-associated lineages, ambrosia beetles are probably the least studied, and constitute an interesting model system for studying the evolutionary transition to an obligate mutualism in insects.

Ambrosia beetles comprise a polyphyletic species assemblage that includes some members of the Scolytinae and Platypodinae subfamilies, in which fungus farming has evolved independently at least 12 times as the dominant ecological strategy [3,4]. Tracking physiological and behavioral traits indicates coadaptation to a mutualistic lifestyle with fungi. For instance, they have evolved specialized integument structures called mycangia, where fungal spores are transported for their cultivation on the walls of intricate gallery systems bored into the xylem of host trees [5-7]. Moreover, the presence of the beetles can trigger physiological responses from the fungus, including the development of fruiting bodies [8], indicating sophisticated inter-species regulatory processes, which are likely the result of intensive long-term coevolution.

Caring for the fungal gardens involves cooperative behavior, and could be related to the decrease of inter- and intra-specific competition for food $[5,9,10]$. It has been proposed that these factors have promoted, through gradual evolutionary processes, the development of a facultative eusocial system in some lineages of ambrosia beetles [11]. While full eusocial behavior in ants and termites includes a division of individuals into groups called castes, with most individuals being unable to reproduce, the social structure observed in some scolytine beetles is less specialized [9-11]. This facultative eusociality is characterized by the overlapping of generations, parental care, division of labor between adults and larvae (age polyethism), and cooperative brood care, as has been described in Xyleborus affinis and Xyleborinus saxeneii [12-14].

Although, strictly speaking, this facultative eusociality has only been described in two species of the Xyleborini tribe $[13,15,16]$, several factors suggest that high levels of sociality are conserved within this monophyletic group. The species of this tribe are haplodiploid, and typically mate among siblings within their natal brood chamber [17-19]. Their high genetic relatedness due to inbreeding and the high costs of dispersal potentially benefits the evolution of cooperative behaviors within the natal gallery (e.g., by fungus gardening, gallery extension, offspring feeding, and cleaning) [20], and could favor the evolution of facultative eusociality.

There are two general and not mutually exclusive hypotheses that explain the molecular mechanisms underlying the evolutionary transition from solitary living to sociality in insects, one based on changes in gene regulation and another based on protein sequence evolution [21-23]. The former, known as the 'genetic toolkit' hypothesis, proposes that deeply conserved genes and gene networks with roles in solitary behaviors are co-opted through changes in gene regulation, leading to the evolution of social traits such as social foraging, reproductive dominance, and age polyethism [21-23]. The second hypothesis postulates that a wide diversity of behaviors and phenotypes arose through the expansion, neofunctionalization, and selection of lineage-specific gene families involved in functions such as carbohydrate metabolism, glandular development, and signal transduction [21-23]. Research supports both general hypotheses, and shows highly conserved genes affecting the expression of complete networks that are caste-biased and influence social traits [24-27], and a small overlap of genes associated with social behavior among distant lineages [26,28-30]. Moreover, role division in animal social groups implies traits which increase the fitness of other members of the group, often at the expense of the individuals harboring the trait. In alloparental care, for example, individuals care for their siblings, instead of devoting those efforts to producing their own brood [6]. These altruistic behaviors can be explained through kin selection and inclusive fitness [31,32], where caring for related individuals increases the overall fitness of the related genotype, as it is shared between individuals 
in some proportion. Therefore, natural selection through inclusive fitness should play a role in the evolution of sociality.

In this context, recent comparative genomic research has identified genomic signals associated with social evolution in ants and termites. Expansion and positive selection of gene families involved in the production and perception of pheromones, caste determination, molting, and metamorphosis has been documented for termites [33]. Meanwhile, Attine ant genomes show very high rates of structural rearrangement [34] and changes in the regulation of gene expression between castes, which could be associated with the rate of evolution of genes with specific caste profiles, as well as genes coding transcriptional regulators [35]. Changes in the molecular evolutionary rate have also been found in organisms with mutualistic lifestyles, such as an accelerated substitution rate in lichen species [36] and increased rates of genome evolution in the Pseudomyrmex ants that form mutualistic rather than generalist relationships with plants of the genera Acacia, Triplaris, and Tachigali [37].

In order to identify genomic signals associated with the evolution of obligate mutualism and putative facultative eusociality in ambrosia beetles, we performed an evolutionary analysis based on the transcriptome sequencing of two ambrosia complexes (beetle and fungi): the polyphagous shot hole borer (PSHB), Euwallacea sp. near fornicatus-Fusarium euwallaceae S. Freeman, Z. Mendel, T. Aoki \& O'Donnell [38,39] and Redbay ambrosia beetle (RAB) Xyleborus glabratus Eichhoff, 1877-Raffaelea lauricola T.C. Harr., Fraedrich \& Aghayeva 2008 [40]. These two complexes belong to the monophyletic Xyleborini tribe, and have been recently described as very hazardous pests for forest health, landscape trees, and the avocado industry, being the causal agents of the diseases commonly known as Fusarium dieback and laurel wilt, respectively [5,39,41-44].

We jointly sequenced the transcriptome of the beetles and the fungi present in their bodies. We performed a screening to separate the fungus-like sequences from the beetle sequences, to assess their functions and their relation to the establishment of their mutualistic interactions.

Finally, we performed a comparative analysis between the transcriptomic data of these two ambrosia beetles and the genomes of other insects. The species considered in the comparative analysis exhibit a wide range of social structures, from solitary to eusocial, and represent four independent origins of sociality (termites, bees, ants, and wasps). Moreover, we included an independent origin of fungus farming mutualism by adding the genomes of four Attini ant species to the comparative analysis. Through this approach, we identified genes that have been selected during the evolution of obligate mutualism and sociality in ambrosia beetles; we further evaluated the relationship between the molecular evolutionary rate and both sociality and obligate mutualism in insects that have convergently evolved these traits.

\section{Materials and Methods}

\subsection{Beetle Collection}

Xyleborus glabratus beetles were collected from silk bay (Persea humilis Nash) trees from Highlands County, Florida showing laurel wilt symptoms, including wilted foliage and strings of boring dust from numerous small holes. Visibly infested branches with diameters larger than $3 \mathrm{~cm}$ were placed in an insect emergence chamber to allow the beetles to emerge from the galleries. Once emerged, the beetles were sorted, identified, and stored in a commercial RNA-stabilizing buffer (RNAlater; Ambion) until RNA isolation. Beetle collection and identification were performed as described previously by Johnson et al. 2018 and Hulcr et al. 2017 [4,5]. Due to the low presence of X. glabratus among the collected beetles, around 5-7 live adult females were used for total RNA isolation.

\subsection{Reared Beetles}

Euwallacea sp. near fornicatus beetles were harvested from established colonies maintained at the University of California Riverside (UCR) Insectary and Quarantine facility. These colonies were initially established from live adult females, collected from avocado wood showing Fusarium 
dieback disease symptoms. Insects were raised on a semi-artificial diet based on the modified recipe of Biedermann et al. 2009 [12]. The diet was comprised of $1.5 \mathrm{~g}$ Wesson's salt, $6 \mathrm{~g}$ sucrose, $6 \mathrm{~g}$ yeast extract, $6 \mathrm{~g}$ potato starch, $12 \mathrm{~g}$ casein, $35 \mathrm{~g}$ agar, $236 \mathrm{~g}$ castor bean sawdust and $685 \mathrm{~mL}$ water. The ingredients were mixed together inside a plastic tub before being packed into $15 \mathrm{~mL}$ Falcon centrifuge tubes. Tubes containing the diet were autoclaved at $120^{\circ} \mathrm{C}$ for $40 \mathrm{~min}$ and allowed to rest for two days before use, to allow the evaporation of excess moisture. A single adult mated female was placed inside each tube, which was sealed with cotton. Beetles could form galleries within the media at $25{ }^{\circ} \mathrm{C}$ and ambient humidity. Every six weeks, female adults were then harvested from colony tubes by removing the media from the tube and dissecting them. A total of 60 live adult females were used for RNA isolation.

\subsection{RNA Isolation, Library Preparation and Sequencing}

Total RNA was isolated with TRIzol reagent (Life Technologies, Carlsbad, CA, USA) and purified with the RNeasy MiniElute kit (QIAGEN, Venlo, The Netherlands) according to the manufacturer's instructions. In the case of E. nr. fornicatus, around $50 \%$ of the collected beetles were dissected to independently extract the total RNA from two sections: head-thorax and abdomen. The remaining insects were used to obtain RNA from the whole body. In the case of X. glabratus, RNA was isolated from the whole body only, due to the limited number of beetles collected. RNA integrity was assessed by chip-based capillary gel electrophoresis using an Agilent 2100 Bioanalyzer system (Agilent Technologies, Santa Clara, CA, USA). The RNA concentration was determined by absorbance at $260 \mathrm{~nm}$ using a NanoDrop 2000 UV-Vis spectrophotometer (Thermo Fisher Scientific, Waltham, MA, USA). A total of 500 ng RNA was used as input material to prepare each of the four RNA-seq libraries used in this study. We used the RNA-seq method based on poly(A) selection, which enriches for eukaryotic mRNA and other polyadenylated RNA molecules. This method is the most common protocol used in whole transcriptome sequencing projects because it provides a broad, detailed, and accurate view of the transcriptional landscape of the protein-coding genes. The TruSeq RNA Sample Preparation Kit (Illumina, San Diego, CA, USA) was used for this purpose, adding specific indexes to each of the sequenced samples. All libraries were sequenced on a NextSeq 550 platform (Illumina) using a $2 \times 150$ bp paired-end sequencing protocol, whereby 150 bases from each side of the DNA strands were sequenced.

\subsection{Data Processing, Assembly, and Functional Annotation}

Prior to the assembly process, low-quality reads were removed from the analysis according to previously defined criteria (Table S1). Paired-end reads with an average Phred quality score lower than 30, and in which at least $90 \%$ of the bases along the sequence failed to meet a Phred quality score of 20 or greater, were filtered out. A python-based script was used for this purpose (https:/ / github.com/Czh3/NGSTools/blob/master/qualityControl.py).

Considering that in ambrosia beetle complexes, both insects and fungi are eukaryotic organisms, and fungi spores are contained inside the mycangia of the beetles, sequences from both (fungi and insect) were expected to be found in the sequenced libraries, although in different proportions. Therefore, before de novo assembly, screening was performed to identify fungus-like sequences, using the Hisat2 2.1.0 program [45]. Reference sequences used consisted on whole genome sequences and/or unique-transcript collections resulting from transcriptomic studies, available in public databases such as JGI (https://genome.jgi.doe.gov/portal/ [46,47]) and GeneBank (https: //www.ncbi.nlm.nih.gov/). Only available sequences from fungi associated with ambrosia beetles were included [48-50] (see Table S2 for more details, [48-53])

The sequences were divided into four datasets based on the process described above: X. glabratus sequences, fungus-like sequences obtained from X. glabratus, E. nr. fornicatus, and fungus-like sequences obtained from E. nr. fornicatus. High-quality paired-end reads from each of these four datasets were independently assembled using Trinity 2.4.0 software [54] (Table S3), producing expressed sequences, which can be called transcript unigenes [55]. Before the annotation process, 
unigenes were processed with AlignWise [56], a pipeline which drives several programs such as BLAST [57], Muscle [58], and GeneWise [59] to identify and correct out-of-frame insertions/deletions in coding regions through a homology-based method. We created a database containing coding sequences and their corresponding proteins from 10 beetle genomes and 11 from other insects for homology-based correction of beetle transcriptomes (Table S4: A1-A3; [33,34,60-73]); the coding sequence and protein sequences of the fungal reference database (Table S2) were used to perform this step for fungus-like sequences.

After correcting the frame-shifts, redundant sequences were eliminated with BlastClust (https: //www.ncbi.nlm.nih.gov/Web/Newsltr/Spring04/blastlab.html). A sequence was considered redundant if it showed an identity of at least $95 \%$ over $90 \%$ or more of the length of the sequences being compared. Only sequences longer than 30 amino acids were kept for further analyses.

To further reduce the presence of contaminating sequences in the two beetle-sequence datasets, we searched for fungus-like sequences that could have been missed in the first screening. This time, considering that distinct fungal species could be associated with the ambrosia beetles, the search was conducted among the unigenes obtained after the assembly and sequences-correction processes. BLASTp similarity searches (e-value $\leq 10^{-10}$ ) were independently performed against two distinct databases, one containing the proteins codified in the whole genome of 811 fungal species obtained from the ENSEMBLFungi genome browser (https:/ / fungi.ensembl.org/species.html), and the other with the proteins codified in the genome of 12 distinct insect species (Table S4: A2). The unigenes with putative homologs identified in both databases were sorted based on bit-score value (from highest to lowest), and were treated as fungal sequences if they had a higher bit-score for the fungal database than for the insects. Other stringency parameters such as the identity and the coverage between the unigenes and their homologs were also considered (identity had to be at least $90 \%$ and coverage at least $70 \%)$.

The annotation process for the four generated transcriptomes included a functional classification and a search for similar sequences in sets of identified proteins in the genome sequences of some species, considered as references mainly due to the quality of their genome annotation and/or the phylogenetic relationships. Functional annotation was carried out by InterproScan 5 analysis $[74,75]$ using the applications Pfam [76,77], TIGRFAM [78], PIRSF [79], and SUPERFAMILY [80]. Functional categories were inferred from gene ontology (GO) information [70]. Furthermore, BLASTp analyses of beetle transcriptomes were conducted using Dendroctonus ponderosae, Drosophila melanogaster, and Apis mellifera as reference species. Moreover, we used Raffaelea lauricola and Fusarium euwallaceae proteomes in the fungus-like sequence, searching (BLASTp) and Gene Ontology (GO) terms enrichment analysis. These proteomes were obtained through the gene model prediction in previously sequenced genomes ([48,49]; Table S2), which are available through the NCBI database. Ab initio and evidence-direct predictor AUGUSTUS $[81,82]$ was used to generate these first versions of the gene models, which were corrected and improved by MAKER pipeline [83,84], entering the whole genome sequences with masked transposable elements, the available transcriptional dataset $[49,85]$, and a reference protein database containing complete proteomes from some ascomycetes available from the JGI database.

\subsection{Data Availability}

Raw transcriptome data of the beetle transcriptomes are available from the NCBI Sequence Read Archive under the accession number PRJNA495609.

\subsection{Ortholog Group Identification}

We identified ortholog genes among X. glabratus, E. nr. fornicatus, and other beetle species (Dendroctonus ponderosae, Leptinotarsa decemlineata, Tribolium castaneum, and Oryctes borbonicus) to gain insight into the selection acting on molecular traits related to the obligate mutualism, as well as to the facultative eusocial behavior displayed by these fungus-farming beetle species. The comparison also 
included the genomes of other insects with a variety of forms of social organization (Apis mellifera, Polistes dominula, Cerapachys birori, Zootermopsis nevadensis, and Cryptotermes secundus), solitary lifestyles (Frankliniella occidentalis), and fungus-farming mutualistic behaviors (Atta cephalotes, Acromyrmex echinatior, Trachymyrmex zeteki, and Cyphomyrmex costatus) (Table S4: A3).

To identify and distinguish homologs and orthologs across compared species, we used the get_homologues.pl script [86,87]. GET_HOMOLOGUES is a versatile software package which combines tools such as OrthoMCL [88] and BLAST [57]. OrthoMCL is an analysis pipeline that uses reciprocal BLAST and the Markov cluster (MCL) algorithm [89] to infer and group orthologs (and paralogs) across multiple taxa. Gene families from predicted proteins were identified using a default MCL inflation value of 1.5 , as well as a threshold value of $10^{-10}$, and a minimum percent of coverage of 75 in the BLAST step. Only those families with a single-copy gene per species were used for phylogenetic inference and evolution rate calculation (see below).

\subsection{Evolutionary Analysis}

We considered all gene families present in 3 or more species for downstream analyses. Multiple sequence alignments were obtained for each gene family, using amino acid sequences with MAFFT [90]. The amino acid alignments were used to obtain codon-based alignments using PAL2NAL v14 [91]. Unigenes with inconsistencies between peptide and nucleotide sequences were discarded from further analysis. Nucleotide alignments were used to construct approximate maximum likelihood (ML) phylogenies with FastTree Version 2.1.9 [92], using the generalized time-reversible evolution model and the Shimodaira-Hasegawa test for branch support calculation.

Characterization of selective processes based on non-synonymous $(\mathrm{dN})$ versus synonymous $(\mathrm{dS})$ rates of protein-coding sequences was performed using the HyPhy v2.2 package (https://veg.github. io/hyphy-site/). FEL-contrast (fixed effect likelihood; [93]) was used to identify individual codons with significant changes in $\mathrm{dN} / \mathrm{dS}$ ratio associated with the adaptation to the mutualistic ecological trait. In order to find lineages which have experienced natural selection pressures, we used aBSREL (adaptive branch-site random effects likelihood; [94]), a method to test for lineage-specific signals of positive selection within a gene family phylogeny.

With the concatenate of 98 single-copy ortholog protein sequences, we constructed an ML phylogeny with PhyML [95] using a JTT+G+I model for substitution, selected by SMS analysis [96] according to Akaike information criterion, and Bootstrap resampling for estimating branch support. Species divergence times were estimated using a Bayesian Markov chain Monte Carlo (MCMC) approach, calculating the approximate likelihood, as implemented in MCMCTree from the PAML 4.9 package [97], using the minimum-divergence ages reported for Hymenoptera, Coleoptera, Thysanoptera and Isoptera clades [98]. We ran two parallel MCMC chains for 11 million generations, sampling every 500 generations and specifying an initial burn-in of one million generations. We confirmed convergence between the two chains using tracer v1.6 [99]. The concatenated single-copy ortholog alignment, the species tree, and the dated phylogeny are available in TreeBase (submission ID 23203).

Previous studies found independent events of acceleration in substitution rates associated with a convergent mutualistic lifestyle in ants of the Pseudomyrmex genus [37]. In order to test for any difference in the substitution rates between mutualists and generalists within our dataset, we analyzed the association between nutritional mutualism with fungi as a binary ecological trait, and evolutionary rates among the species of insects studied. To this end, we used TraitRareProp [100,101], which detects trait-dependent evolutionary rate shifts in sequence sites. Terminal branches were assigned to a state of obligate mutualism, 1 or 0 . All the attine ants (Cyphomyrmex costatus, Atta cephalotes, Acromyrmex echinatior, Trachymyrmex zeteki), ambrosia beetles (X. glabratus and E. nr. fornicatus), and Dendroctonus ponderosae received a mutualist state assignment, based on the knowledge of their mutualistic symbiosis with fungi. Due to the intermediate nature of the mutualism in D. ponderosae, we ran this same analysis considering only strict fungus farming species and excluding this species, to analyze the differences 
between these two types of mutualism (Figure S5). Additionally, we conducted a TraitRateProp analysis with sociality as ecological binary trait, considering eusocial (Apis mellifera, Polistes dominula, Cerapachys birori, Atta cephalotes, Acromyrmex echinatior, Trachymyrmex zeteki, Cyphomyrmex costatus, Zootermopsis nevadensis, and Cryptotermes secundus) and facultative eusocial species (X. glabratus and E. nr. fornicatus) as social insects.

Finally, GO term enrichment analysis was performed using topGO R package (https: //bioconductor.org/packages/release/bioc/html/topGO.html) to evaluate the possibility of over-represented terms among the genes with signals of positive selection, using all genes present at the transcriptome of each organism as the gene universe. To assess possible GO terms over-represented among the genes with decreased or increased evolutionary rates associated with mutualism, all the single-copy ortholog genes were used as the gene universe. In both cases we focused on the biological process (BP) category and used Fisher's exact test for the statistics. A $p$-value of $\leq 0.01$ was considered the threshold to select significant results.

\subsection{Differential Expression Analysis}

We analyzed the differential expression patterns of beetle and fungal genes between the three datasets of E. nr. fornicatus-Fusarium euwallaceae complex: abdomen, head-thorax and whole body. We used RSEM 1.2.17 [102] to quantify the gene expression and test for significant expression differences between tissues.

Paired unassembled reads of each sample were aligned to the unigene transcript sequences with Bowtie 2 [103]. From this mapping, we obtained a matrix of raw read counts and TMM-normalized FPKMs (i.e., trimmed mean of $\mathrm{M}$ values-normalized fragments per $\mathrm{kb}$ of transcript per million reads mapped) expression values per unigene transcript. For the differential expression analysis, we considered that each sample in our data represented a single biological replicate and used edgeR package [104] to calculate the negative binomial dispersion across conditions from the read counts of genes, using a dispersion parameter of 0.1 . For the test of significant tissue enrichment, $\mathrm{p}$ values from the differential expression analyses were adjusted for false discovery rate (FDR) with the Benjamini and Hochberg correction [105]. Only genes with $p$-adjusted $\leq 0.01$ were considered as differentially expressed genes. According to this and total expression profiles, each gene then received a category of organ localization: organ-specific, organ-enriched, or whole body.

\section{Results}

We generated two de novo transcriptome assemblies of 221.3 and $110.6 \mathrm{Mb}$, for E. nr. fornicatus and X. glabratus respectively (Table 1). $82 \%$ of E. nr. fornicatus and $79 \%$ of X. glabratus predicted unigenes were functionally annotated with either InterProScan5 or BLASTp. The genome with the highest proportion of homologous genes was $D$. ponderosae for both ambrosia beetle transcriptomes.

Table 1. Assembly and annotation statistics for the two ambrosia beetle transcriptomes sequenced in this study.

\begin{tabular}{ccc}
\hline & Euwallacea sp. near fornicatus & Xyleborus glabratus \\
\hline Total high-quality paired reads & $61,919,467$ & $68,243,721$ \\
Total number of assembled transcripts & 248,739 & 150,163 \\
N50 (bp) & 1636 & 1261 \\
Total assembled bases & $221,342,598$ & $110,621,067$ \\
Average contig length (bp) & 889.86 & 736.67 \\
Total number of predicted unigenes & 68,490 & 46,814 \\
InterproScan5 annotated unigenes & 56,315 & 34,612 \\
BLASTp annotated unigenes & 55,115 & 37,188 \\
\hline
\end{tabular}

Based on the comparison of unassembled reads and assembled transcripts against the fungal databases, we identified 16,738 putatively fungal unigenes obtained from X. glabratus and 10,925 from 
E. nr. fornicatus transcriptomes, of which 95.03 and $90.94 \%$ showed homology with Raffaelea lauricola and Fusarium euwallaceae proteomes respectively and were considered as separate datasets for further analyses.

Enrichment analysis of fungal-related sequences against $F$. euwallaceae and $R$. lauricola proteomes revealed $10 \mathrm{GO}$ categories enriched in both fungus-like gene sets within $E$. nr. fornicatus and X. glabratus transcriptomes, involved in constitutive functional categories such as translation, vesicle transport and exocytosis, splicing, ATP hydrolysis, proteolysis, and protein folding (See Table S5). Particularly, the $X$. glabratus fungal sequence set was enriched in the isoprenoid biosynthetic process category (GO:0008299).

\subsection{Gene Family Analysis}

A gene family analysis for E. nr. fornicatus and X. glabratus transcriptomes was conducted with genomes from 14 other insects (TableS4: A3), to evaluate the genomic signals associated with the evolution of mutualistic lifestyle and social behavior in ambrosia beetles.

A total of 107,701 gene family clusters were retrieved, where 2475 families were shared by most of the analyzed species $(\sim 90 \%)$ and 10,565 were moderately conserved among taxa $(\sim 60 \%)$. The core of homologous genes conserved in all compared species consisted of 946 gene families.

E. nr. fornicatus and X. glabratus were the datasets with the largest proportion of unique gene families (23,412 and 24,945 respectively), mostly consisting of a single member that may be attributable to the presence of gene isoforms in both transcriptome datasets. Furthermore, both ambrosia beetle species shared 6946 gene families, of which 1714 are potentially unique for this clade and lack homologues in any other of the compared genomes, while containing mainly unclassified proteins, as well as genes related to the cellular process (GO:0009987) and cellular component organization or biogenesis (GO:0071840) functional categories.

Moreover, we observed 2238 clusters shared by ambrosia beetles and eusocial insects. Within this group the most represented subcategories were signal transduction (GO:0007165) and transcription, DNA-dependent (GO:0006351). Two of the largest gene families of this eusocial insect and ambrosia beetle-shared group, consisting of 102 and 163 members, corresponded to nervous system-associated genes, such as the family of kainate receptor [106] and Down syndrome cell adhesion molecule-like protein (Dscam; [107]), respectively.

\subsection{Genes under Selection in the Xyleborini Ambrosia Beetle Lineage}

We evaluated whether selective pressures $(\mathrm{dN} / \mathrm{dS})$ vary among the branches of each gene family phylogeny with aBSREL. We identified 1425 terminal branches with signals of positive selection ( $p \leq 0.05$ in Likelihood ratio tests for episodic positive selection, Holm-Bonferroni corrected) in gene family phylogenies across 16 insect species (Figure S1). From these, we found 176 and 166 coding genes under positive selection in X. glabratus and E. nr. fornicatus respectively (Tables S6 and S7, Figures S2-S4).

Among all the genes under selection, there were 80 Interpro accessions shared by positively selected genes of both species. These genes were mainly involved in sugar transport (facilitated trehalose transporter Tret1; [108]), abiotic stress response (Heat shock protein 70 family; [109]), transcriptional regulation (protein drumstick, E3 ubiquitin-protein ligase Parkin and ZZ-type zinc finger-containing protein 3; [110-112]), G-protein receptors (GPCRs), signal transduction (Rab3 GTPase-activating protein, Synembrin-A, tyrosine kinase receptor Cad96Ca, tuberin and G-protein coupled receptor 143; [113-117]), development and muscular morphogenesis (Afadin, Ecdysteroid kinase, ankyrin repeat domain-containing protein 16-like, unconventional myosin-XVIIIa, Hemicentin-1; [118-121]), and several genes involved in the development and function of the nervous system (Nesprin-1, SLIT-NTRK protein 1, neuroligin-2, neuronal PAS-domain-containing protein 4, Amphysin; [122-125]). 
Among the genes under selection in the E. nr. fornicatus transcriptome, 100 were expressed in the whole body, 45 were enriched or specific for abdomen and 19 for head-thorax (see Table S6 for more details). Signals of selection were found on the sex peptide receptor $[126,127]$ and galactosylgalactosylxylosyl protein 3-beta-glucuronosyltransferase P (GlcAT-P; [128]) genes, which are exclusively transcribed on the head-thorax. Particularly, genes under selection are significantly enriched ( $p \leq 0.01$ in Fisher's exact test) in the GO functional categories of fructose metabolism (GO:0006000) in E. nr. fornicatus and apoptotic DNA fragmentation and protein processing (GO:0016485, GO:0006309) in X. glabratus transcriptomes, respectively.

\subsection{Changes in Evolutionary Rates Related to Fungus-Farming Mutualism and Sociality}

The species tree obtained from the phylogenetic analysis maintains all insect order clades as monophyletic groups, with bootstrap support values from 0.95 to 1 in all branches. The estimated age of divergence between Xyleborini species is approximately $25.11 \pm 13.31$ million years ago (mya), and $88.56 \pm 30.36$ mya since divergence from D. ponderosae (Figure 1A). In the context of the species phylogeny, we evaluated the potential association of mutualism and sociality with variation in molecular substitution rates between species. The TraitRateProp analysis was performed in three groups of single-copy orthologs: considering all species ( $\alpha, 98$ orthologs), excluding species from the Isoptera order ( $\beta, 164$ orthologs), and only considering the Coleoptera order ( $\gamma, 468$ orthologs). The analysis of the latter subset of orthologs constitutes the direct comparison between the two ambrosia species (as mutualists and facultative eusocial species) and other beetles.

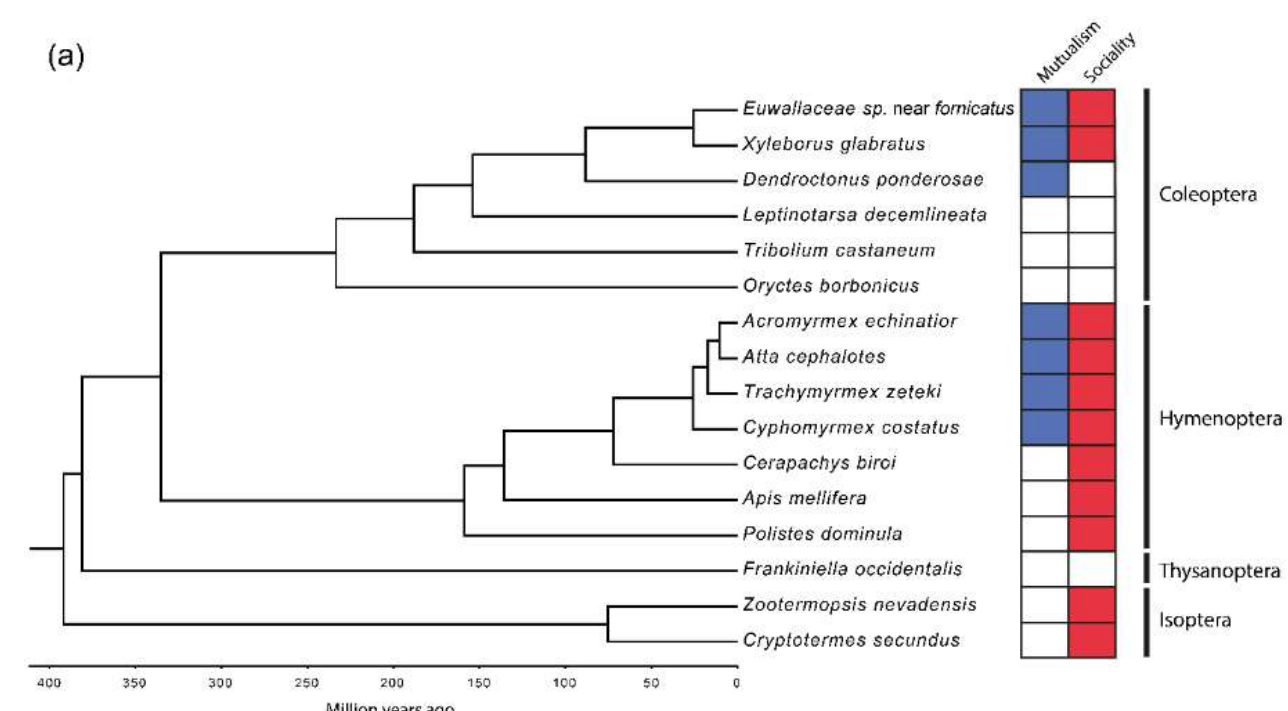

(b)

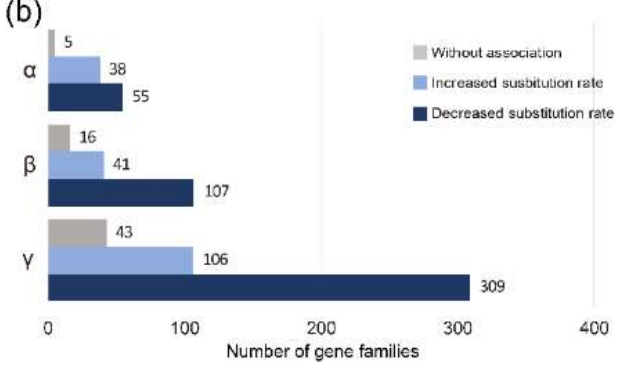

(c)

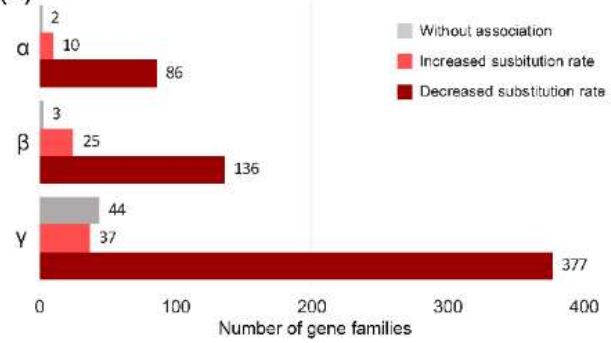

Figure 1. (a) Time-calibrated phylogeny based on 98 sequences from single-copy orthologs and mutualist-social behavior categories. (b) Single copy ortholog groups with substitution rate variations associated with mutualistic nutritional symbiosis with fungi. (c) Single copy ortholog groups with substitution rate variations associated with social behavior. $\alpha$ : Isoptera + Thysanoptera + Hymenoptera + Coleoptera; $\beta$ : Thysanoptera +Hymenoptera + Coleoptera; $\gamma$ : Coleoptera. 
The greatest proportion of single-copy orthologs in all the groups revealed a significantly negative association ( $p \leq 0.05$ in chi-squared likelihood ratio test) between the rate of sequence evolution and the mutualistic lifestyle, as well as the social category (Tables S8 and S9). Although this association was predominantly negative (genes with a slower molecular rate of evolution in mutualistic and social species), genes with a positive association were also found, showing an accelerated molecular evolutionary rate in mutualistic and social lineages (Figure 1B,C). No particular GO functional category was observed to be significantly enriched in single-copy orthologs with either an increased or decreased rate associated with the two traits.

All genes representing a negative association between mutualism and evolutionary rate likewise exhibited a negative association with sociality. Furthermore, there was a larger number of gene families positively related to mutualism than to sociality. As trait-dependent accelerations in the rate of molecular evolution can reflect events of either positive or relaxed selection, we analyzed the evidence of natural selection in proteins with a positive association between a trait and substitution rate. We thus identified several genes with evidence of positive selection and convergent evolutionary rate acceleration associated with sociality, mutualism, and both traits (Table 2).

Table 2. Genes with trait-dependent accelerations in the rate of molecular evolution, and with evidence of positive selection.

\begin{tabular}{|c|c|c|c|}
\hline Cluster ID & Association with & BLASTp Annotation & Ortholog Group \\
\hline 199572_KRT80184 & Mutualism & methylosome subunit pICln & $\alpha$ \\
\hline 199849_KRT80461 & Mutualism & Rab-protein 6 (Rab6) & $\alpha$ \\
\hline 200376_KRT80988 & Mutualism & ribosomal RNA small subunit methyltransferase NEP1 & $\alpha$ \\
\hline 203911_KRT84523 & Mutualism & phosphatidylethanolamine-binding protein homolog F40A3.3 & $\alpha$ \\
\hline 198969_KRT79581 & Both & ribosome biogenesis regulatory protein homolog & $\alpha$ \\
\hline 201287_KRT81899 & Sociality & ubiquitin carboxyl-terminal hydrolase 30 & $\alpha$ \\
\hline 203022_KRT83634 & Sociality & phosphoacetylglucosamine mutase-like & $\alpha$ \\
\hline 180851_KRT82102 & Both & $\begin{array}{l}\text { NADH dehydrogenase (ubiquinone) 1-alpha subcomplex 9, 39kDa } \\
\text { (Ndufa9) }\end{array}$ & $\beta$ \\
\hline 181368_KRT82619 & Both & Bax inhibitor 1 (BaxI1) & $\beta$ \\
\hline 182416_KRT83667 & Both & vesicle transport through interaction with t-SNAREs homolog $1 \mathrm{~A}$ & $\beta$ \\
\hline 182600_KRT83851 & Both & $\begin{array}{l}\text { UDP-N-acetylglucosamine-dolichyl-phosphate } \\
\text { N-acetylglucosaminephosphotransferase }\end{array}$ & $\beta$ \\
\hline 183558_KRT84809 & Sociality & ribosome-recycling factor, mitochondrial & $\beta$ \\
\hline 185607_KRT86858 & Sociality & malate dehydrogenase, mitochondrial & $\beta$ \\
\hline 176873_KRT78124 & Mutualism & poly (ADP-ribose) glycohydrolase ARH3 & $\beta$ \\
\hline 177777_KRT79028 & Mutualism & DNA replication complex GINS protein SLD5 & $\beta$ \\
\hline 181622_KRT82873 & Mutualism & ubiquitin domain-containing protein $1 / 2$ & $\beta$ \\
\hline 185046_KRT86297 & Mutualism & MFS-type transporter C6orf192 homolog & $\beta$ \\
\hline 100143_KRT79886 & Both & cysteine-rich with EGF-like domain protein 2 & $\gamma$ \\
\hline 101937_KRT81680 & Both & Cornichon protein & $\gamma$ \\
\hline 103130_KRT82873 & Both & ubiquitin domain-containing protein 1 & $\gamma$ \\
\hline 99990_KRT79733 & Both & suppressor of hairless protein & $\gamma$ \\
\hline 100907_KRT80650 & Both & transmembrane protein 127 & $\gamma$ \\
\hline 99195_KRT78938 & Both & voltage-dependent anion-selective channel protein 2 & $\gamma$ \\
\hline
\end{tabular}

\section{Discussion}

Mutualistic symbiotic interactions represent a source of evolutionary novelty, and consequently modify the genomes of the species involved [129-131]. Our study provides novel insights on the molecular and genomic processes involved in the evolution of sociality and obligate fungus farming in ambrosia beetles of the Xyleborini tribe. Based on natural selection and substitution rate analyses of ortholog gene families, several genes and pathways potentially associated with these evolutionary transitions were identified.

\subsection{Evolutionary Changes Possibly Associated with Nutritional Symbiosis with Fungi}

The evolution of fungus farming in ambrosia beetles is associated with a dietary specialization related to the low content of relevant nutrients in the phloem-based diet of their bark beetle ancestors. Such specialization implies the increase of dietary nitrogen $[9,132]$ and the acquisition of other important molecules such as sterols, required for metamorphosis and reproduction $([9,10,133])$. 
Among the genes with signals of positive selection in the transcriptomes of E. nr. fornicatus and X. glabratus, fructose metabolism and proteolysis functional categories were found to be enriched. Nitrogen can be acquired from a protein-rich diet through proteolysis, therefore selection in genes encoding proteolytic enzymes, such as trypsins, could constitute an evolutionary adjustment to the changed nitrogen availability in a fungus-based diet. Some adjustments related to nutrient acquisition have been observed in fungus-farming ant genomes. For instance, the gene losses in arginine biosynthetic pathways or the reduction in the serine protease gene family have been observed in ants, and are thought to be associated with variations in dietary nitrogen following fungus farming evolution $[68,71]$.

On the other hand, signals of positive selection were observed in genes related to carbohydrate metabolism and transport in both ambrosia beetle species. First, 6-phosphofructo-2-kinase/fructose-2,6-bisphosphatase (PFKFB) is an enzyme that catalyzes the synthesis and degradation of fructose 2,6-bisphosphate, which functions as a signal molecule for glycolysis and gluconeogenesis modulation [134]. Secondly, trehalose transporter Tret1, which was also found to be under positive selection, regulates levels of trehalose (as the main storage sugar) in insect hemolymph, as well as its release from the body fat and incorporation of trehalose as a carbon source into other tissues such as muscle and testis [108]. Trehalose also appears to have a role for buffering sugar fluctuation in response to food composition and quantity [135], both of which could potentially change in a transition from a phloem-based diet to a fungal-based diet.

Molecular evolution associated with changes in diet as a consequence of farming and domestication has been widely studied in humans (e.g., [136-139]). In humans, these mechanisms involve the evolution of genes related to metabolism, nutrient homeostasis, digestion, sensory perception, appetite control, and morphological development of the digestive system [139]. In addition, many changes related to nutrient acquisition in the genomes of fungus-farming ants [34,68,71], as well as changes in mass-specific metabolic rates through fungus-farming evolution stages in Attini ants, have also been documented [21]. Therefore, selection on genes that participate in energy and nutrient homeostasis may be associated with dietary specialization after fungi farming evolved in the Xyleborini tribe.

\subsection{Evolutionary Changes Possibly Related to the Evolution of Behavior and Sociality.}

Many behavioral adaptations can be recognized in X. glabratus and E. nr. fornicatus since the divergence and radiation of the Xyleborini tribe. These beetles bore deep into the wood instead of bark [8], inbreed [4], and farm fungi [3,4], involving activities such as pathogen monitoring and control and selective use of substrate for fungi farming [10,22]. There is also evidence that suggests that these ambrosia beetles could display a facultative eusocial system [11], characterized by overlapping generations, cooperative care of the offspring, and age polyethism [12-14].

As previously mentioned, the general hypotheses about evolution of sociality suggest that the co-option of conserved gene networks, as well as selection, and fast protein evolution are involved in the emergence of social behaviors and phenotypes [21-23], while natural selection through inclusive fitness should play a critical role in the evolution of sociality [31,32]. We found signals of positive selection in several genes involved in transcriptional regulation, reproduction, signal transduction development, and nervous system functioning, which could be associated with the transition to sociality in ambrosia beetles, as well as with other major changes in behavior since the divergence of this lineage.

The first group of genes under selective pressure found to be associated with social behavior were related to the transcriptional regulation of gene expression. Previous studies in eusocial organisms such as bees suggest that evolutionary changes in gene regulation are critical for the appearance of specialized phenotypes $[140,141]$ and the production of social traits such as social foraging, reproductive dominance, and alloparental care [24,32,142], the latter having been observed in ambrosia beetles [8]. Genes involved in transcriptional regulation and with signals of positive selection 
in X. glabratus and E. nr. fornicatus identified in this work are related to digestive tract development (protein drumstick), mitochondrial integrity and oxidative stress response (E3 ubiquitin-protein ligase parkin), chromatin organization (ZZ-type zinc finger-containing protein 3), and development of olfactory and sensory organs (basic helix-loop-helix amos transcription factor and suppressor of hairless protein). Suppressor of hairless gene also shows an accelerated evolution in both ambrosia beetles compared to other species of the Coleoptera order, suggesting that this gene has an important role in the adaptation of these species. Since olfactory and sensory systems regulate many insect behaviors [143,144], such as the communication and recognition between individuals in social organisms [31], adaptive signals observed in these genes could be involved in the evolution of behavior and sociality within this group. Moreover, transcriptional regulation can be related to the evolution of other apomorphic traits in these species, therefore the transcriptional profiles need to be analyzed across different members of an ambrosia beetle colony to test these hypotheses.

The second group relates to genes involved in reproductive behavior. Sex peptide receptor was observed to be under positive selection in E. nr. fornicatus. This gene plays a role in female post-mating behavior shifts [126,127] and the release of stored sperm for fertilization [145] in D. melanogaster. Gene networks regulating reproduction, and particularly those regulating the changes between reproductive and non-reproductive behavioral stages, are predicted to have pleiotropic effects on reproductive traits and social behaviors such as age polyethism and parental care $[23,146]$. The changes in this gene could be related to delayed reproduction and dispersal, promoting altruistic behaviors as observed in the facultative eusocial beetle Xyleborinus saxesenii [13].

The third group comprises genes implicated in GPCRs signal transduction. Ligands of GPCRs include hormones, peptide and non-peptide neurotransmitters, odorant molecules, growth factors, and light, and signaling through these proteins is important for controlling processes such as development, reproduction, behavior, and feeding [147]. Chemical communication is widely recognized to have a critical role in social behavior in hymenopterans [148] and termites [33]. Concerning ambrosia beetles, recent findings document the production of and response to two volatiles compounds (2-heneicosanone and 2-tricosanone) by three cryptic species of $E$. near fornicatus [polyphagous shot hole borer (PSHB), Kuroshio shot hole borer (KSHB), and tea shot hole borer (TSHB)], [149]. These compounds are produced in unique ratios and work like pheromones, showing species-specific attraction and repellency. Previous works have also detected these two volatile compounds in the mandibular gland secretions of the stingless bee Scaptotrigona postica [150], and in the subterranean termite Reticulitermes flavipes [151], two insect species which display high levels of sociality. Therefore, molecular adaptations associated with communication between members of a population could be playing an important role in the coordination of several behaviors, and in the emergence of sociality in ambrosia beetles [31].

The fourth group includes development-associated genes, such as the cornichon protein. It has been proposed that the evolution of developmental pathways is important for increasing termite eusociality, which is characterized by differentiated castes represented by distinct developmental stages [33]. Even though ambrosia beetles do not display caste differentiation, they present a division of labor between larvae and adults, which in turn could be related to selective pressures towards future cast differentiation. Alternatively, developmental adaptation could play an important role in the formation of specialized structures, such as mycangia, as well as other morphological changes present in these species, like the increase of sexual dimorphism and the decrease in size, since diverging from its common ancestor with $D$. ponderosae.

The last group of genes associated with sociality and under selective pressure was involved in the nervous system and sensory functions. The signals of positive selection on genes involved in the development and function of the nervous system in both E. nr. fornicatus and X. glabratus suggest an adaptive evolution in the ambrosia beetles towards changes in behavior. Among these genes, we found several proteins conserved in mammals and insects required for synaptogenesis (amphysin, liprin, neuroligin-2, neurexin-4, SLIT-NTRK protein 1, GlcAT-P; [128,152-154], nervous 
system development (neuronal PAS-domain-containing protein 4, Neural/ectodermal development factor, IMP-L2; [155,156], neurotransmitter transport, (sodium neurotransmitter symporter; [157] and, as previously mentioned, development of sensory organs (basic helix-loop-helix amos transcription factor and suppressor of hairless protein [158-160]. Neuroligin-2 has been directly associated with social behavior in D. melanogaster [161] and GlcAT-P shows caste-specific transcriptional patterns during brain development in Apis mellifera [128]. We found that GlcAT-P is expressed in the head-thorax of $E$. nr. fornicatus, which points to an adaptation related to social behavior in ambrosia beetles.

Furthermore, two of the largest gene families shared by ambrosia beetles and eusocial insects are involved in the function of the nervous system (a receptor that controls synaptic transduction: kainate receptor [106], and the neuronal guidance factor Down syndrome cell adhesion molecule-like protein (Dscam; [107]) observed to have effects on locomotor behavior and fecundity respectively, further suggesting the importance of genes associated with behavior evolution in ambrosia beetles.

\subsection{Possible Causes of Accelerated or Decreased Evolutionary Rates}

We found significant differences in the substitution rates between mutualistic and non- mutualistic, as well as social and nonsocial, insects. Most of the single-copy orthologs showed a slower evolutionary rate in social and mutualist phylogenetically independent lineages. More genes showed slower evolutionary rates in social and strict fungus-farming lineages than in general mutualistic ones (Figures 1 and S5). Because all strict fungus farming considered display social behaviors, the genes that show this trait decrease in their evolutionary rates are more likely to be associated to the evolution of sociality than with mutualism.

Slowly evolving proteins could be under strong purifying selection during the evolution of social lineages, reflecting a constrained protein evolution in these species. Low evolutionary rates associated with highly specialized sociality have been previously observed in bees with different levels of social organization [140], and in honey bees compared to other insects such as fruit flies [56]. This is in general agreement with the 'genetic toolkit' hypothesis, suggesting a set of highly conserved genes but an increased gene regulation during social evolution.

On the other hand, we observed several single-copy orthologs with accelerated rates related to mutualism and strict fungus framing. Accelerated rates could be a result of a positive or relaxed selection, but also a consequence of nonadaptive evolution, such as mechanisms related to demography due to genetic drift. However, the changes observed in global dN/dS ratios between mutualistic and non-mutualistic lineages (Figure S6) strongly suggest that the evolutionary rate acceleration related to mutualism is mainly due to changes in selective pressures acting on these genes. Some of these single-copy ortholog genes provide evidence of positive selection (Table 2), pointing to a convergent adaptive evolution towards this lifestyle, as well as the evolution of social organization.

\subsection{Transcriptional Fungal Profiles}

Different fungal species establish symbiotic interactions with bark and ambrosia beetles, having several levels of promiscuity and specificity [162,163]. In natural conditions, beetles are exposed to several microbial species and present multipartite interactions with different fungi. It has been proposed that specificity in these interactions largely depends on environmental factors such as temperature $[164,165]$, as well as on differences in dietary benefits for beetles $[9,162]$ in different life-cycle and gallery formation stages [166]. Therefore, exploring the functional capabilities of the different symbionts is needed for evaluation of these hypotheses.

Functional profiles of fungus-like genes transcribed in the body of E. nr. fornicatus and X. glabratus share most of the enriched functional categories. These categories can be related to fungus growth, but also to their interaction with the beetles. Particularly, the Isoprenoid biosynthesis GO category was present in fungus-like transcriptome from both types of ambrosia beetles, but enriched only in the body of X. glabratus. This biosynthetic process is needed for the synthesis of sterol, as well as other terpenoids. Besides, many of the scolytid aggregation pheromones are isoprenoids $[167,168]$, 
including ipsdienol, ipsenol, and frontalin [169]. In particular, (1S,4R)- p-menth-2-en-1-ol (also known as quercivorol) is documented to function as an attractant kairomone for members of the $E$. nr. fornicatus species complex, and this compound is likely produced by the symbiotic fungi [149]. This aggregation compound has been identified in other ambrosia beetle species like Ewuallacea spp. and Platypus quercivorus (Coleoptera: Platypodidae) [170]. Therefore, the enrichment of this category reflects that these molecules could have an important role in establishing fungus-beetle interaction.

\section{Concluding Remarks}

Evolutionary transition to mutualism and social organization in ambrosia beetles appears to involve protein changes driven by natural selection that could constitute diet-related and social behavior adaptations to the new selective pressures of fungus-farming lifestyles. Selection appears to target different components with similar pathways to those that have been reported in different insect lineages for the transition to mutualism/sociality.

Moreover, across-lineage comparison allowed us to identify the convergent changes in protein evolution related to sociality and mutualism transitions. We observed conserved genes with a decreased molecular evolution, mainly associated with a sociality trait, and an accelerated evolution related to selective pressures across the mutualistic lineages studied.

Comparative analyses of transcriptomic and genomic data prevented us from performing a more detailed search of evolutionary signals, such as expansion and contraction of gene families or synteny. Future genomic analysis within the Scolytinae subfamily and Xyleborini tribe is needed to describe the evolution of mutualism, and to test the social evolution hypotheses, considering the differences between independent origins of these traits. Additionally, studies on the transcriptomics of beetles with comparable replicates between species, development stages, and sexes are fundamental to assess the detailed role of transcriptional gene regulation in the mechanisms underlying these complex traits.

Supplementary Materials: The following are available online at http:/ /www.mdpi.com/2075-1729/9/1/2/s1, Table S1: Overview of Illumina short read sequencing for the two ambrosia complexes and quality control, Table S2: External genomic fungal data sources used for the first fungus-like sequences screening, Table S3: Assembly and annotation statistics of the ambrosial complexes transcriptomes generated in this study, Table S4: External genomic insect data sources, Table S5: GO term counts of fungus-ike sequences retrieved from $E$. nr. fornucatus and X. glabratus, Table S6: Summary of genes in Euwallacea sp. near fornicatus under positive selection, Table S7: Summary of genes in Xyleborus glabratus under positive selection, Table S8: Summary of conserved gene families with evolutionary rate associated to mutualism, Table S9: Summary of conserved gene families with evolutionary rate associated to sociality, Figure S1: Genes under selection identified with aBSREL analysis $(p \leq 0.05$ in Likelihood ratio test for episodic diversifying positive selection at Holm-Bonferroni corrected) for each insect species, Figure S2: Gene Ontology (GO) Biological Process categories associated with the genes with signals of positive selection in X. glabratus and E. nr. fornicuatus, Figure S3: Gene Ontology (GO) Cellular Component categories associated with the genes with signals of positive selection in X. glabratus and E. nr. fornicuatus, Figure S4: Gene Ontology (GO) Molecular Process categories associated with the genes with signals of positive selection in X. glabratus and E. nr. fornicuatus, Figure S5: Comparison between TraitRateProp analysis. Single copy ortholog groups with changes in its substitution rate associated with strict fungus farming (Attini and ambrosia beetles species) and with general nutritional mutualism with fungi (Attini ants, ambrosia beetles and D. ponderosae species).

Author Contributions: Conceptualization, E.I.-L. and J.B.; Methodology, J.B., J.B.-R., M.V.-R.-L. and A.C.-T.; Formal Analysis, J.B., J.B.-R., M.V.-R.-L., A.C.-T. and E.I.-L.; Investigation, J.B., J.B.-R., M.V.-R.-L., A.C.-T., E.A. v.W., D.C., R.S., A.E., E.V., A.A.-S., A.L., L.A.I.-J, C.A.P.-T., and E.I.-L.; Resources, E.I.-L., E.A., D.C., R.S., A.E.; Data Curation, J.B., J.B.-R., M.V.-R.-L. and A.C.-T.; Writing-Original Draft Preparation, J.B..; Writing-Review \& Editing, J.B., J.B.-R. and E.I.-L.; Visualization, J.B.; Supervision, E.I.-L.; Funding Acquisition, E.I.-L.

Funding: This research was funded by the National Forestry Commission of Mexico (Comisión Nacional Forestal or CONAFOR) grant number 265677 and by the National Fund for Scientific and Technological Development (Fondo Nacional de Desarrollo Científico y Tecnológico or FORDECYT) grant number 292399.

Acknowledgments: We would like to thank Richard Stouthamer (from UCR) and Octavio Menocal, Luisa Cruz, and Rita Duncan (from UF) who provided us the Euwallacea sp. near fornicatus and X. glabratus ambrosia beetles, respectively. Also, we thank Martín Aluja Schuneman Hofer for funding management with the Mexican phytosanitary authorities.

Conflicts of Interest: The authors declare no conflict of interest. 


\section{References}

1. Mueller, U.G.; Gerardo, N. Fungus-farming insects: Multiple origins and diverse evolutionary histories. Proc. Natl. Acad. Sci. USA 2002, 99, 15247-15249. [CrossRef] [PubMed]

2. Mueller, U.G.; Gerardo, N.M.; Aanen, D.K.; Six, D.L.; Schultz, T.R. The evolution of agriculture in insects. Annu. Rev. Ecol. Evol. Syst. 2005, 36, 563-595. [CrossRef]

3. Jordal, B.H.; Cognato, A.I. Molecular phylogeny of bark and ambrosia beetles reveals multiple origins of fungus farming during periods of global warming. BMC Evol. Biol. 2012, 12, 133. [CrossRef] [PubMed]

4. Johnson, A.J.; McKenna, D.D.; Jordal, B.H.; Cognato, A.I.; Smith, S.M.; Lemmon, A.R.; Lemmon, E.M.; Hulcr, J. Phylogenomics clarifies repeated evolutionary origins of inbreeding and fungus farming in bark beetles (Curculionidae, Scolytinae). Mol. Phylogenet. Evol. 2018, 127, 229-238. [CrossRef] [PubMed]

5. Hulcr, J.; Stelinski, L.L. The ambrosia symbiosis: From evolutionary ecology to practical management. Annu. Rev. Entomol. 2017, 62, 285-303. [CrossRef] [PubMed]

6. Vega, F.E.; Hofstetter, R.W. Bark Beetles: Biology and Ecology of Native and Invasive Species; Elsevier Science: Amsterdam, The Netherlands, 2014.

7. Cruz, L.F.; Rocio, S.A.; Duran, L.G.; Menocal, O.; Garcia-Avila, C.D.J.; Carrillo, D. Developmental biology of Xyleborus bispinatus (Coleoptera: Curculionidae) reared on an artificial medium and fungal cultivation of symbiotic fungi in the beetle's galleries. Fungal Ecol. 2018, 35, 116-126. [CrossRef]

8. Kirkendall, L.R.; Biedermann, P.H.W.; Jordal, B.H. Chapter 3-Evolution and diversity of bark and ambrosia beetles. In Bark Beetles; Vega, F.E., Hofstetter, R.W., Eds.; Academic Press: San Diego, CA, USA, 2015; pp. 85-156.

9. Bleiker, K.P.; Six, D.L. Dietary benefits of fungal associates to an eruptive herbivore: Potential implications of multiple associates on host population dynamics. Environ. Entomol. 2007, 36, 1384-1396. [CrossRef] [PubMed]

10. Six, D.L. Ecological and evolutionary determinants of bark beetle-Fungus symbioses. Insects 2012, 3, 339-366. [CrossRef]

11. Biedermann, P.H.W.; Rohlfs, M. Evolutionary feedbacks between insect sociality and microbial management. Curr. Opin. Insect Sci. 2017, 22, 92-100. [CrossRef] [PubMed]

12. Biedermann, P.H.; Klepzig, K.D.; Taborsky, M. Fungus cultivation by ambrosia beetles: Behavior and laboratory breeding success in three Xyleborine species. Environ. Entomol. 2009, 38, 1096-1105. [CrossRef]

13. Biedermann, P.H.; Taborsky, M. Larval helpers and age polyethism in ambrosia beetles. Proc. Natl. Acad. Sci. USA 2011, 108, 17064-17069. [CrossRef] [PubMed]

14. Biedermann, P.H.; Klepzig, K.D.; Taborsky, M.; Six, D.L. Abundance and dynamics of filamentous fungi in the complex ambrosia gardens of the primitively eusocial beetle Xyleborinus saxesenii Ratzeburg (coleoptera: Curculionidae, scolytinae). FEMS Microbiol. Ecol. 2013, 83, 711-723. [CrossRef] [PubMed]

15. Peer, K.; Taborsky, M. Delayed dispersal as a potential route to cooperative breeding in ambrosia beetles. Behav. Ecol. Sociobiol. 2007, 61, 729-739. [CrossRef]

16. Biedermann, P.H.W.; Klepzig, K.D.; Taborsky, M. Costs of delayed dispersal and alloparental care in the fungus-cultivating ambrosia beetle Xyleborus affinis Eichhoff (Scolytinae: Curculionidae). Behav. Ecol. Sociobiol. 2011, 65, 1753-1761. [CrossRef]

17. Kirkendall, L.R. Ecology and evolution of biased sex ratios in bark and ambrosia beetles. In Evolution and Diversity of Sex Ratio in Insects and Mites; Wrensch, D.L., Ebbert, M.A., Eds.; Chapman \& Hall: New York, NY, USA, 1993; pp. 235-345.

18. Normark, B.B.; Jordal, B.H.; Farrell, B.D. Origin of a haplodiploid beetle lineage. Proc. R. Soc. B Biol. Sci. 1999, 266, 2253-2253. [CrossRef]

19. Peer, K.; Taborsky, M. Outbreeding depression, but no inbreeding depression in haplodiploid ambrosia beetles with regular sibling mating. Evol. Int. J. Org. Evol. 2005, 59, 317-323. [CrossRef]

20. Kirkendall, L.R.; Kent, D.S.; Raffa, K.F. Interactions among males, females and offspring in bark and ambrosia beetles: The significance of living in tunnels for the evolution of social behavior. In The Evolution of Social Behaviour in Insects and Arachnids; Crespi, B.J., Choe, J.C., Eds.; Cambridge University Press: Cambridge, UK, 1997; pp. 181-215.

21. Shik, J.Z.; Santos, J.C.; Seal, J.N.; Kay, A.; Mueller, U.G.; Kaspari, M. Metabolism and the rise of fungus cultivation by ants. Am. Nat. 2014, 184, 364-373. [CrossRef] 
22. Ranger, C.M.; Biedermann, P.H.W.; Phuntumart, V.; Beligala, G.U.; Ghosh, S.; Palmquist, D.E.; Mueller, R.; Barnett, J.; Schultz, P.B.; Reding, M.E.; et al. Symbiont selection via alcohol benefits fungus farming by ambrosia beetles. Proc. Natl. Acad. Sci. USA 2018, 115, 4447-4452. [CrossRef]

23. Rehan, S.M.; Toth, A.L. Climbing the social ladder: The molecular evolution of sociality. Trends Ecol. Evol. 2015, 30, 426-433. [CrossRef]

24. Toth, A.L.; Varala, K.; Henshaw, M.T.; Rodriguez-Zas, S.L.; Hudson, M.E.; Robinson, G.E. Brain transcriptomic analysis in paper wasps identifies genes associated with behaviour across social insect lineages. Proc. Biol. Sci. 2010, 277, 2139-2148. [CrossRef]

25. Toth, A.L.; Tooker, J.F.; Radhakrishnan, S.; Minard, R.; Henshaw, M.T.; Grozinger, C.M. Shared genes related to aggression, rather than chemical communication, are associated with reproductive dominance in paper wasps (Polistes metricus). BMC Genom. 2014, 15, 75. [CrossRef] [PubMed]

26. Mikheyev, A.S.; Linksvayer, T.A. Genes associated with ant social behavior show distinct transcriptional and evolutionary patterns. eLife 2015, 4, e04775. [CrossRef] [PubMed]

27. Woodard, S.H.; Fischman, B.J.; Venkat, A.; Hudson, M.E.; Varala, K.; Cameron, S.A.; Clark, A.G.; Robinson, G.E. Genes involved in convergent evolution of eusociality in bees. Proc. Natl. Acad. Sci. USA 2011, 108, 7472-7477. [CrossRef] [PubMed]

28. Harpur, B.A.; Kent, C.F.; Molodtsova, D.; Lebon, J.M.D.; Alqarni, A.S.; Owayss, A.A.; Zayed, A. Population genomics of the honey bee reveals strong signatures of positive selection on worker traits. Proc. Natl. Acad. Sci. USA 2014, 111, 2614-2619. [CrossRef] [PubMed]

29. Johnson, B.R.; Tsutsui, N.D. Taxonomically restricted genes are associated with the evolution of sociality in the honey bee. BMC Genom. 2011, 12, 164. [CrossRef] [PubMed]

30. Sumner, S. The importance of genomic novelty in social evolution. Mol. Ecol. 2014, 23, 26-28. [CrossRef] [PubMed]

31. Weitekamp, C.A.; Libbrecht, R.; Keller, L. Genetics and evolution of social behavior in insects. Annu. Rev. Genet. 2017, 51, 219-239. [CrossRef] [PubMed]

32. Toth, A.L.; Rehan, S.M. Molecular evolution of insect sociality: An eco-evo-devo perspective. Annu. Rev. Entomol. 2017, 62, 419-442. [CrossRef] [PubMed]

33. Harrison, M.C.; Jongepier, E.; Robertson, H.M.; Arning, N.; Bitard-Feildel, T.; Chao, H.; Childers, C.P. Hemimetabolous genomes reveal molecular basis of termite eusociality. Nat. Ecol. Evol. 2018, 2, 557-566. [CrossRef]

34. Nygaard, S.; Hu, H.; Li, C.; Schiott, M.; Chen, Z.; Yang, Z.; Xie, Q.; Ma, C.; Deng, Y.; Dikow, R.B.; Rabeling, C.; et al. Reciprocal genomic evolution in the ant-fungus agricultural symbiosis. Nat. Commun. 2016, 7, 12233. [CrossRef]

35. Favreau, E.; Martínez-Ruiz, C.; Rodrigues Santiago, L.; Hammond, R.L.; Wurm, Y. Genes and genomic processes underpinning the social lives of ants. Curr. Opin. Insect Sci. 2018, 25, 83-90. [CrossRef] [PubMed]

36. Lutzoni, F.; Pagel, M. Accelerated evolution as a consequence of transitions to mutualism. Proc. Natl. Acad. Sci. USA 1997, 94, 11422-11427. [CrossRef] [PubMed]

37. Rubin, B.E.R.; Moreau, C.S. Comparative genomics reveals convergent rates of evolution in ant-plant mutualisms. Nat. Commun. 2016, 7, 12679. [CrossRef] [PubMed]

38. Stouthamer, R.; Rugman-Jones, P.; Thu, P.Q.; Eskalen, A.; Thibault, T.; Hulcr, J.; Wang, L.-J.; Jordal, B.H.; Chen, C.-Y.; Cooperband, M.; et al. Tracing the origin of a cryptic invader: Phylogeography of the Euwallacea fornicatus (Coleoptera: Curculionidae: Scolytinae) species complex. Agric. For. Entomol. 2017, 19, 366-375. [CrossRef]

39. Freeman, S.; Sharon, M.; Maymon, M.; Mendel, Z.; Protasov, A.; Aoki, T.; Eskalen, A.; O’Donnell, K. Fusarium euwallaceae sp. Nov.-A symbiotic fungus of Euwallacea sp., an invasive ambrosia beetle in Israel and California. Mycologia 2013, 105, 1595-1606. [CrossRef] [PubMed]

40. Mayfield, A.E.I.; Pena, J.E.; Crane, J.H.; Smith, J.A.; Branch, C.L.; Ottoson, E.D.; Hughes, M. Ability of the redbay ambrosia beetle (Coleoptera: Curculionidae: Scolytinae) to bore into young avocado (Lauraceae) plants and transmit the laurel wilt pathogen (Raffaelea sp.). Fla. Entomol. 2008, 91, 485-487. [CrossRef]

41. Kasson, M.T.; O’Donnell, K.; Rooney, A.P.; Sink, S.; Ploetz, R.C.; Ploetz, J.N.; Konkol, J.L.; Carrillo, D.; Freeman, S.; Mendel, Z.; et al. An inordinate fondness for Fusarium: Phylogenetic diversity of fusaria cultivated by ambrosia beetles in the genus Euwallacea on avocado and other plant hosts. Fungal Genet. Biol. 2013, 56, 147-157. [CrossRef] 
42. O'Donnell, K.; Libeskind-Hadas, R.; Hulcr, J.; Bateman, C.; Kasson, M.T.; Ploetz, R.C.; Konkol, J.L.; Ploetz, J.N.; Carrillo, D.; Campbell, A.; et al. Invasive asian Fusarium-Euwallacea ambrosia beetle mutualists pose a serious threat to forests, urban landscapes and the avocado industry. Phytoparasitica 2016, 44, 435-442. [CrossRef]

43. Carrillo, D.; Cruz, L.F.; Kendra, P.E.; Narvaez, T.I.; Montgomery, W.S.; Monterroso, A.; De Grave, C.; Cooperband, M.F. Distribution, pest status and fungal associates of Euwallacea nr. fornicatus in florida avocado groves. Insects 2016, 7, 55.

44. Carrillo, D.; Duncan, R.E.; Peña, J.E. Ambrosia beetles (Coleoptera: Curculionidae: Scolytinae) that breed in avocado wood in florida. Fla. Entomol. 2012, 95, 573-579. [CrossRef]

45. Kim, D.; Langmead, B.; Salzberg, S.L. HISAT: A fast spliced aligner with low memory requirements. Nat. Methods 2015, 12, 357-360. [CrossRef] [PubMed]

46. Grigoriev, I.V.; Cullen, D.; Goodwin, S.B.; Hibbett, D.; Jeffries, T.W.; Kubicek, C.P.; Kuske, C.; Magnuson, J.K.; Martin, F.; Spatafora, J.W.; et al. Fueling the future with fungal genomics. Mycology 2011, 2, 192-209.

47. Grigoriev, I.V.; Nikitin, R.; Haridas, S.; Kuo, A.; Ohm, R.; Otillar, R.; Riley, R.; Salamov, A.; Zhao, X.; Korzeniewski, F.; et al. Mycocosm portal: Gearing up for 1000 fungal genomes. Nucleic Acids Res. 2014, 42, D699-D704. [CrossRef] [PubMed]

48. Ibarra-Laclette, E.; Sánchez-Rangel, D.; Hernández-Domínguez, E.; Pérez-Torres, C.A.; Ortiz-Castro, R.; Villafán, E.; Alonso-Sánchez, A.; Rodríguez-Hass, B.; López-Buenfil, A.; García-Avila, C.; et al. Draft genome sequence of the phytopathogenic fungus Fusarium euwallaceae, the causal agent of fusarium dieback. Genome Announc. 2017, 5, e00881-e00817. [CrossRef] [PubMed]

49. Vanderpool, D.; Bracewell, R.R.; McCutcheon, J.P. Know your farmer: Ancient origins and multiple independent domestications of ambrosia beetle fungal cultivars. Mol. Ecol. 2018, 27, 2077-2094. [CrossRef] [PubMed]

50. Wingfield, B.D.; Barnes, I.; Wilhelm de Beer, Z.; De Vos, L.; Duong, T.A.; Kanzi, A.M.; Naidoo, K.; Nguyen, H.D.T.; Santana, Q.C.; Sayari, M.; et al. IMA genome-f 5: Draft genome sequences of Ceratocystis eucalypticola, Chrysoporthe cubensis, C. deuterocubensis, Davidsoniella virescens, Fusarium temperatum, Graphilbum fragrans, Penicillium nordicum, and Thielaviopsis musarum. IMA Fungus 2015, 6, 493-506. [CrossRef] [PubMed]

51. Wingfield, B.D.; Ades, P.K.; Al-Naemi, F.A.; Beirn, L.A.; Bihon, W.; Crouch, J.A.; de Beer, Z.W.; De Vos, L.; Duong, T.A.; Fields, C.J.; et al. IMA genome-f 4: Draft genome sequences of Chrysoporthe austroafricana, Diplodia scrobiculata, Fusarium nygamai, Leptographium lundbergii, Limonomyces culmigenus, Stagonosporopsis tanaceti, and Thielaviopsis punctulata. IMA Fungus 2015, 6, 233-248. [CrossRef]

52. Endoh, R.; Suzuki, M.; Okada, G.; Takeuchi, Y.; Futai, K. Fungus symbionts colonizing the galleries of the ambrosia beetle Platypus quercivorus. Microb. Ecol. 2011, 62, 106-120. [CrossRef]

53. De Marco, L.; Epis, S.; Capone, A.; Martin, E.; Bozic, J.; Crotti, E.; Ricci, I.; Sassera, D. The genomes of four Meyerozyma caribbica isolates and novel insights into the Meyerozyma guilliermondii species complex. Genes Genomes Genet. 2018, 8, 755-759. [CrossRef]

54. Grabherr, M.G.; Haas, B.J.; Yassour, M.; Levin, J.Z.; Thompson, D.A.; Amit, I.; Adiconis, X.; Fan, L.; Raychowdhury, R.; Zeng, Q.; et al. Full-length transcriptome assembly from RNA-seq data without a reference genome. Nat. Biotechnol. 2011, 29, 644-652. [CrossRef]

55. Shu, S.; Chen, B.; Zhou, M.; Zhao, X.; Xia, H.; Wang, M. De novo sequencing and transcriptome analysis of Wolfiporia cocos to reveal genes related to biosynthesis of triterpenoids. PLoS ONE 2013, 8, e71350. [CrossRef] [PubMed]

56. Evans, T.; Loose, M. ALIGNWISE: A tool for identifying protein-coding sequence and correcting frame-shifts. BMC Bioinform. 2015, 16, 376. [CrossRef] [PubMed]

57. Altschul, S.F.; Gish, W.; Miller, W.; Myers, E.W.; Lipman, D.J. Basic local alignment search tool. J. Mol. Biol. 1990, 215, 403-410. [CrossRef]

58. Edgar, R.C. MUSCLE: Multiple sequence alignment with high accuracy and high throughput. Nucleic Acids Res. 2004, 32, 1792-1797. [CrossRef] [PubMed]

59. Birney, E.; Clamp, M.; Durbin, R. Genewise and genomewise. Genome Res. 2004, 14, 988-995. [CrossRef] [PubMed]

60. Poelchau, M.; Childers, C.; Moore, G.; Tsavatapalli, V.; Evans, J.; Lee, C.-Y.; Lin, H.; Lin, J.-W.; Hackett, K. The i5k workspace@NAL_Enabling genomic data access, visualization and curation of arthropod genomes. Nucleic Acids Res. 2015, 43, D714-D719. [CrossRef] [PubMed] 
61. Meyer, J.M.; Markov, G.V.; Baskaran, P.; Herrmann, M.; Sommer, R.J.; Rödelsperger, C. Draft genome of the scarab beetle Oryctes borbonicus on La Réunion Island. Genome Biol. Evol. 2016, 8, 2093-2105. [CrossRef]

62. Fallon, T.R.; Lower, S.E.; Chang, C.-H.; Bessho-Uehara, M.; Martin, G.J.; Bewick, A.J.; Behringer, M.; Debat, H.J.; Wong, I.; Day, J.C.; et al. Firefly genomes illuminate parallel origins of bioluminescence in beetles. eLife 2018, 7, e36495. [CrossRef]

63. McKenna, D.D.; Scully, E.D.; Pauchet, Y.; Hoover, K.; Kirsch, R.; Geib, S.M.; Mitchell, R.F.; Waterhouse, R.M.; Ahn, S.-J.; Arsala, D.; et al. Genome of the asian longhorned beetle (Anoplophora glabripennis), a globally significant invasive species, reveals key functional and evolutionary innovations at the beetle-plant interface. Genome Biol. 2016, 17, 227. [CrossRef]

64. Schoville, S.D.; Chen, Y.H.; Andersson, M.N.; Benoit, J.B.; Bhandari, A.; Bowsher, J.H.; Brevik, K.; Cappelle, K.; Chen, M.-J.M.; Childers, A.K.; et al. A model species for agricultural pest genomics: The genome of the colorado potato beetle, Leptinotarsa decemlineata (Coleoptera: Chrysomelidae). Sci. Rep. 2018, 8, 1931. [CrossRef]

65. Keeling, C.I.; Yuen, M.M.; Liao, N.Y.; Roderick Docking, T.; Chan, S.K.; Taylor, G.A.; Palmquist, D.L.; Jackman, S.D.; Nguyen, A.; Li, M.; et al. Draft genome of the mountain pine beetle, Dendroctonus ponderosae hopkins, a major forest pest. Genome Biol. 2013, 14, R27. [CrossRef] [PubMed]

66. Tribolium Genome Sequencing Consortium. The genome of the model beetle and pest Tribolium castaneum. Nature 2008, 452, 949. [CrossRef] [PubMed]

67. The Honeybee Genome Sequencing Consortium. Insights into social insects from the genome of the honeybee Apis mellifera. Nature 2006, 443, 931. [CrossRef]

68. Suen, G.; Teiling, C.; Li, L.; Holt, C.; Abouheif, E.; Bornberg-Bauer, E.; Bouffard, P.; Caldera, E.J.; Cash, E.; Cavanaugh, A.; et al. The genome sequence of the leaf-cutter ant Atta cephalotes reveals insights into its obligate symbiotic lifestyle. PLoS Genet. 2011, 7, e1002007. [CrossRef]

69. Oxley, P.R.; Ji, L.; Fetter-Pruneda, I.; McKenzie, S.K.; Li, C.; Hu, H.; Zhang, G.; Kronauer, D.J. The genome of the clonal raider ant Cerapachys biroi. Curr. Biol. 2014, 24, 451-458. [CrossRef] [PubMed]

70. Standage, D.S.; Berens, A.J.; Glastad, K.M.; Severin, A.J.; Brendel, V.P.; Toth, A.L. Genome, transcriptome and methylome sequencing of a primitively eusocial wasp reveal a greatly reduced DNA methylation system in a social insect. Mol. Ecol. 2016, 25, 1769-1784. [CrossRef]

71. Nygaard, S.; Zhang, G.; Schiott, M.; Li, C.; Wurm, Y.; Hu, H.; Zhou, J.; Ji, L.; Qiu, F.; Rasmussen, M.; et al. The genome of the leaf-cutting ant Acromyrmex echinatior suggests key adaptations to advanced social life and fungus farming. Genome Res. 2011, 21, 1339-1348. [CrossRef]

72. Terrapon, N.; Li, C.; Robertson, H.M.; Ji, L.; Meng, X.; Booth, W.; Chen, Z.; Childers, C.P.; Glastad, K.M.; Gokhale, K.; et al. Molecular traces of alternative social organization in a termite genome. Nat. Commun. 2014, 5, 3636. [CrossRef]

73. Adams, M.D.; Celniker, S.E.; Holt, R.A.; Evans, C.A.; Gocayne, J.D.; Amanatides, P.G.; Scherer, S.E.; Li, P.W.; Hoskins, R.A.; Galle, R.F.; et al. The genome sequence of Drosophila melanogaster. Science 2000, 287, 2185. [CrossRef]

74. Jones, P.; Binns, D.; Chang, H.Y.; Fraser, M.; Li, W.; McAnulla, C.; McWilliam, H.; Maslen, J.; Mitchell, A.; Nuka, G.; et al. Interproscan 5: Genome-scale protein function classification. Bioinformatics 2014, 30, 1236-1240. [CrossRef]

75. Finn, R.D.; Attwood, T.K.; Babbitt, P.C.; Bateman, A.; Bork, P.; Bridge, A.J.; Chang, H.-Y.; Dosztányi, Z.; El-Gebali, S.; Fraser, M.; et al. Interpro in 2017-beyond protein family and domain annotations. Nucleic Acids Res. 2017, 45, D190-D199. [CrossRef] [PubMed]

76. Finn, R.D.; Coggill, P.; Eberhardt, R.Y.; Eddy, S.R.; Mistry, J.; Mitchell, A.L.; Potter, S.C.; Punta, M.; Qureshi, M.; Sangrador-Vegas, A.; et al. The pFam protein families database: Towards a more sustainable future. Nucleic Acids Res. 2016, 44, D279-D285. [CrossRef] [PubMed]

77. Punta, M.; Coggill, P.C.; Eberhardt, R.Y.; Mistry, J.; Tate, J.; Boursnell, C.; Pang, N.; Forslund, K.; Ceric, G.; Clements, J.; et al. The pFam protein families database. Nucleic Acids Res. 2012, 40, D290-D301. [CrossRef] [PubMed]

78. Haft, D.H.; Selengut, J.D.; Richter, R.A.; Harkins, D.; Basu, M.K.; Beck, E. TIGRFAMS and genome properties in 2013. Nucleic Acids Res. 2013, 41, D387-D395. [CrossRef] [PubMed] 
79. Wu, C.H.; Nikolskaya, A.; Huang, H.; Yeh, L.S.; Natale, D.A.; Vinayaka, C.R.; Hu, Z.Z.; Mazumder, R.; Kumar, S.; Kourtesis, P.; et al. PIRSF: Family classification system at the protein information resource. Nucleic Acids Res. 2004, 32, D112-D114. [CrossRef] [PubMed]

80. de Lima Morais, D.A.; Fang, H.; Rackham, O.J.L.; Wilson, D.; Pethica, R.; Chothia, C.; Gough, J. SUPERFAMILY 1.75 including a domain-centric gene ontology method. Nucleic Acids Res. 2011, 39, D427-D434. [CrossRef] [PubMed]

81. Stanke, M.; Tzvetkova, A.; Morgenstern, B. AUGUSTUS at EGASP: Using est, protein and genomic alignments for improved gene prediction in the human genome. Genome Biol. 2006, 7. [CrossRef]

82. Stanke, M.; Diekhans, M.; Baertsch, R.; Haussler, D. Using native and syntenically mapped cDNA alignments to improve de novo gene finding. Bioinformatics 2008, 24, 637-644. [CrossRef]

83. Cantarel, B.L.; Korf, I.; Robb, S.M.C.; Parra, G.; Ross, E.; Moore, B.; Holt, C.; Alvarado, A.S.; Yandell, M. MAKER: An easy-to-use annotation pipeline designed for emerging model organism genomes. Genome Res. 2008, 18. [CrossRef]

84. Campbell, M.S.; Holt, C.; Moore, B.; Yandell, M. Genome annotation and curation using MAKER and MAKER-P. Curr. Protoc. Bioinform. 2014, 48. [CrossRef]

85. Sánchez-Rangel, D.; Hernández-Domínguez, E.E.; Pérez-Torres, C.; Ortiz-Castro, R.; Villafán, E.; Rodríguez-Haas, B.; Alonso-Sánchez, A.; López-Buenfil, A.; Carrillo-Ortiz, N.; Hernández-Ramos, L.; et al. Environmental $\mathrm{pH}$ modulates genetic responses related to pathogenicity in the fungus Fusarium $\mathrm{sp}$. associated with KSHB Euwallaceae sp. Near fornicatus. BMC Genom. 2018, 19, 721.

86. Contreras-Moreira, B.; Vinuesa, P. GET_HOMOLOGUES, a versatile software package for scalable and robust microbial pangenome analysis. Appl. Environ. Microbiol. 2013, 79, 7696-7701. [CrossRef] [PubMed]

87. Contreras-Moreira, B.; Cantalapiedra, C.P.; Garcia-Pereira, M.J.; Gordon, S.P.; Vogel, J.P.; Igartua, E.; Casas, A.M.; Vinuesa, P. Analysis of plant pan-genomes and transcriptomes with GET_HOMOLOGUES-EST, a clustering solution for sequences of the same species. Front. Plant Sci. 2017, 8, 184. [CrossRef] [PubMed]

88. Li, L.; Stoeckert, C.J., Jr.; Roos, D.S. ORTHOMCL: Identification of ortholog groups for Eukaryotic Genomes. Genome Res. 2003, 13, 2178-2189. [CrossRef] [PubMed]

89. Enright, A.J.; Van Dongen, S.; Ouzounis, C.A. An efficient algorithm for large-scale detection of protein families. Nucleic Acids Res. 2002, 30, 1575-1584. [CrossRef] [PubMed]

90. Yamada, K.; Katoh, K.; Tomii, K. 1P267 application of novel amino acid substitution matrix, MIQS, to the mafft multiple sequence aligner (22c. Bioinformatics: Comparative genomics, poster, the 52nd annual meeting of the biophysical society of japan(bsj2014)). Seibutsu Butsuri 2014, 54, S185. [CrossRef]

91. Suyama, M.; Torrents, D.; Bork, P. PAL2NAL: Robust conversion of protein sequence alignments into the corresponding codon alignments. Nucleic Acids Res. 2006, 34, W609-W612. [CrossRef] [PubMed]

92. Price, M.N.; Dehal, P.S.; Arkin, A.P. FASTTREE 2-Approximately maximum-likelihood trees for large alignments. PLoS ONE 2010, 5, e9490. [CrossRef]

93. Pond, S.L.; Frost, S.D.; Grossman, Z.; Gravenor, M.B.; Richman, D.D.; Brown, A.J. Adaptation to different human populations by HIV-1 revealed by codon-based analyses. PLoS Comput. Biol. 2006, 2, e62.

94. Smith, M.D.; Wertheim, J.O.; Weaver, S.; Murrell, B.; Scheffler, K.; Kosakovsky Pond, S.L. Less is more: An adaptive branch-site random effects model for efficient detection of episodic diversifying selection. Mol. Biol. Evol. 2015, 32, 1342-1353. [CrossRef]

95. Guindon, S.; Dufayard, J.F.; Lefort, V.; Anisimova, M.; Hordijk, W.; Gascuel, O. New algorithms and methods to estimate maximum-likelihood phylogenies: Assessing the performance of PhyML 3.0. Syst. Biol. 2010, 59, 307-321. [CrossRef]

96. Lefort, V.; Longueville, J.E.; Gascuel, O. SMS: Smart model selection in PhyML. Mol. Biol. Evol. 2017, 34, 2422-2424. [CrossRef] [PubMed]

97. Yang, Z. PAML 4: Phylogenetic analysis by maximum likelihood. Mol. Biol. Evol. 2007, 24, $1586-1591$. [CrossRef] [PubMed]

98. Misof, B.; Liu, S.; Meusemann, K.; Peters, R.S.; Donath, A.; Mayer, C.; Frandsen, P.B.; Ware, J.; Flouri, T.; Beutel, R.G.; et al. Phylogenomics resolves the timing and pattern of insect evolution. Science 2014, 346, 763-767. [CrossRef] [PubMed]

99. Rambaut, A.; Suchard, M.A.; Xie, D.; Drummond, A.J. TRACER v1.6. Available online: http:/ / tree.bio.ed.ac. uk/software/tracer/ (accessed on 14 October 2018). 
100. Levy Karin, E.; Wicke, S.; Pupko, T.; Mayrose, I. An integrated model of phenotypic trait changes and site-specific sequence evolution. Syst. Biol. 2017, 66, 917-933. [CrossRef] [PubMed]

101. Levy Karin, E.; Ashkenazy, H.; Wicke, S.; Pupko, T.; Mayrose, I. TraitRateProp: A web server for the detection of trait-dependent evolutionary rate shifts in sequence sites. Nucleic Acids Res. 2017, 45, W260-W264. [CrossRef] [PubMed]

102. Li, B.; Dewey, C.N. RSEM: Accurate transcript quantification from RNA-seq data with or without a reference genome. BMC Bioinform. 2011, 12, 323. [CrossRef] [PubMed]

103. Langmead, B.; Salzberg, S.L. Fast gapped-read alignment with Bowtie 2. Nat. Methods 2012, 9, 357-359. [CrossRef]

104. Robinson, M.D.; McCarthy, D.J.; Smyth, G.K. EDGER: A bioconductor package for differential expression analysis of digital gene expression data. Bioinformatics 2010, 26, 139-140. [CrossRef]

105. Benjamini, Y.; Hochberg, Y. Controlling the false discovery rate: A practical and powerful approach to multiple testing. J. R. Stat. Soc. Ser. B Methodol. 1995, 57, 289-300. [CrossRef]

106. Li, Y.; Dharkar, P.; Han, T.H.; Serpe, M.; Lee, C.H.; Mayer, M.L. Novel functional properties of Drosophila CNS glutamate receptors. Neuron 2016, 92, 1036-1048. [CrossRef] [PubMed]

107. Funada, M.; Hara, H.; Sasagawa, H.; Kitagawa, Y.; Kadowaki, T. A honey bee dsCAM family member, abscam, is a brain-specific cell adhesion molecule with the neurite outgrowth activity which influences neuronal wiring during development. Eur. J. Neurosci. 2007, 25, 168-180. [CrossRef] [PubMed]

108. Kanamori, Y.; Saito, A.; Hagiwara-Komoda, Y.; Tanaka, D.; Mitsumasu, K.; Kikuta, S.; Watanabe, M.; Cornette, R.; Kikawada, T.; Okuda, T. The trehalose transporter 1 gene sequence is conserved in insects and encodes proteins with different kinetic properties involved in trehalose import into peripheral tissues. Insect Biochem. Mol. Biol. 2010, 40, 30-37. [CrossRef] [PubMed]

109. Chang, Y.W.; Zhang, X.X.; Chen, J.Y.; Lu, M.X.; Gong, W.R.; Du, Y.Z. Characterization of three heat shock protein 70 genes from Liriomyza trifolii and expression during thermal stress and insect development. Bull. Entomol. Res. 2018. [CrossRef] [PubMed]

110. Iwaki, D.D.; Johansen, K.A.; Singer, J.B.; Lengyel, J.A. drumstick, bowl, and lines are required for patterning and cell rearrangement in the Drosophila embryonic hindgut. Dev. Biol. 2001, 240, 611-626. [CrossRef] [PubMed]

111. Unschuld, P.G.; Dächsel, J.; Darios, F.; Kohlmann, A.; Casademunt, E.; Lehmann-Horn, K.; Dichgans, M.; Ruberg, M.; Brice, A.; Gasser, T.; et al. Parkin modulates gene expression in control and ceramide-treated PC12 cells. Mol. Biol. Rep. 2006, 33, 13-32. [CrossRef] [PubMed]

112. Mi, W.; Zhang, Y.; Lyu, J.; Wang, X.; Tong, Q.; Peng, D.; Xue, Y.; Tencer, A.H.; Wen, H.; Li, W.; et al. The ZZ-type zinc finger of ZZZ3 modulates the atac complex-mediated histone acetylation and gene activation. Nat. Commun. 2018, 9, 3759. [CrossRef]

113. Seachrist, J.L.; Ferguson, S.S.G. Regulation of G protein-coupled receptor endocytosis and trafficking by rab gtpases. Life Sci. 2003, 74, 225-235. [CrossRef]

114. Miller, K.G.; Emerson, M.D.; McManus, J.R.; Rand, J.B. RIC-8 (synembryn): A novel conserved protein that is required for $\mathrm{G}(\alpha)$ alpha signaling in the C. elegans nervous system. Neuron 2000, 27, 289-299. [CrossRef]

115. Sopko, R.; Perrimon, N. Receptor tyrosine kinases in Drosophila development. Cold Spring Harb. Perspect. Biol. 2013, 5. [CrossRef]

116. Krymskaya, V.P. Tumour suppressors hamartin and tuberin: Intracellular signalling. Cell. Signal. 2003, 15, 729-739. [CrossRef]

117. Nowling, R.J.; Abrudan, J.L.; Shoue, D.A.; Abdul-Wahid, B.; Wadsworth, M.; Stayback, G.; Collins, F.H.; McDowell, M.A.; Izaguirre, J.A. Identification of novel arthropod vector G protein-coupled receptors. Parasites Vectors 2013, 6, 150. [CrossRef] [PubMed]

118. Ikeda, W.; Nakanishi, H.; Miyoshi, J.; Mandai, K.; Ishizaki, H.; Tanaka, M.; Togawa, A.; Takahashi, K.; Nishioka, H.; Yoshida, H.; et al. Afadin: A key molecule essential for structural organization of cell-cell junctions of polarized epithelia during embryogenesis. J. Cell Biol. 1999, 146, 1117. [CrossRef] [PubMed]

119. Ito, Y.; Yasuda, A.; Sonobe, H. Synthesis and phosphorylation of ecdysteroids during ovarian development in the silkworm, Bombyx mori. Zool. Sci. 2008, 25, 721-727. [CrossRef] [PubMed]

120. Katzemich, A.; West, R.J.H.; Fukuzawa, A.; Sweeney, S.T.; Gautel, M.; Sparrow, J.; Bullard, B. Binding partners of the kinase domains in Drosophila obscurin and their effect on the structure of the flight muscle. J. Cell Sci. 2015, 128, 3386-3397. [CrossRef] [PubMed] 
121. Chowdhury, A.; Hasselbach, L.; Echtermeyer, F.; Jyotsana, N.; Theilmeier, G.; Herzog, C. Fibulin-6 regulates pro-fibrotic TGF- $\beta$ responses in neonatal mouse ventricular cardiac fibroblasts. Sci. Rep. 2017, 7, 42725. [CrossRef]

122. Morel, V.; Lepicard, S.; Rey, A.N.; Parmentier, M.L.; Schaeffer, L. Drosophila nesprin-1 controls glutamate receptor density at neuromuscular junctions. Cell. Mol. Life Sci. 2014, 71, 3363-3379. [CrossRef]

123. Brose, K.; Bland, K.S.; Wang, K.H.; Arnott, D.; Henzel, W.; Goodman, C.S.; Tessier-Lavigne, M.; Kidd, T. Slit proteins bind robo receptors and have an evolutionarily conserved role in repulsive axon guidance. Cell 1999, 96, 795-806. [CrossRef]

124. Xing, G.; Li, M.; Sun, Y.; Rui, M.; Zhuang, Y.; Lv, H.; Han, J.; Jia, Z.; Xie, W. Neurexin-neuroligin 1 regulates synaptic morphology and functions via the WAVE regulatory complex in Drosophila neuromuscular junction. eLife 2018, 7, e30457. [CrossRef]

125. Klaric, T.; Lardelli, M.; Key, B.; Koblar, S.; Lewis, M. Activity-dependent expression of neuronal PAS domain-containing protein 4 (npas4a) in the developing zebrafish brain. Front. Neuroanat. 2014, 8, 148.

126. Kubli, E. Sexual behaviour: A receptor for sex control in Drosophila females. Curr. Biol. 2008, 18, R210-R212. [CrossRef] [PubMed]

127. Yapici, N.; Kim, Y.-J.; Ribeiro, C.; Dickson, B.J. A receptor that mediates the post-mating switch in Drosophila reproductive behaviour. Nature 2007, 451, 33. [CrossRef] [PubMed]

128. Barchuk, A.R.; dos Santos, G.D.; Dias Caneschi, R.; de Paula Junior, D.E.; Moda, L.M.R. The ontogenetic saga of a social brain. Apidologie 2018, 49, 32-48. [CrossRef]

129. Delaux, P.M.; Varala, K.; Edger, P.P.; Coruzzi, G.M.; Pires, J.C.; Ane, J.M. Comparative phylogenomics uncovers the impact of symbiotic associations on host genome evolution. PLoS Genet. 2014, 10, e1004487. [CrossRef] [PubMed]

130. De Fine Licht, H.H.; Boomsma, J.J.; Tunlid, A. Symbiotic adaptations in the fungal cultivar of leaf-cutting ants. Nat. Commun. 2014, 5, 5675. [CrossRef] [PubMed]

131. Sudakaran, S.; Kost, C.; Kaltenpoth, M. Symbiont acquisition and replacement as a source of ecological innovation. Trends Microbiol. 2017, 25, 375-390. [CrossRef] [PubMed]

132. Ayres, M.P.; Wilkens, R.T.; Ruel, J.J.; Lombardero, M.J.; Vallery, E. Nitrogen budgets of phloem-feeding bark beetles with and without symbiotic fungi. Ecology 2000, 81, 2198-2210. [CrossRef]

133. Norris, D.M.; Baker, J.M.; Chu, H.M. Symbiontic interrelationships between microbes and ambrosia beetles. III. Ergosterol as the source of sterol to the insect. Ann. Entomol. Soc. Am. 1969, 62, 413-414. [CrossRef]

134. Rider, M.H.; Bertrand, L.; Vertommen, D.; Michels, Paul A.; Rousseau, Guy G.; Hue, L. 6-phosphofructo-2-kinase/fructose-2,6-bisphosphatase: Head-to-head with a bifunctional enzyme that controls glycolysis. Biochem. J. 2004, 381, 561. [CrossRef] [PubMed]

135. Yasugi, T.; Yamada, T.; Nishimura, T. Adaptation to dietary conditions by trehalose metabolism in Drosophila. Sci. Rep. 2017, 7, 1619. [CrossRef]

136. Du, X.H.; Gray, P.M. Evolutionary Gem: Evolution of lactase persistence. West. Undergr. Res. J. 2017, 8, 1-3. [CrossRef]

137. Liebert, A.; Lopez, S.; Jones, B.L.; Montalva, N.; Gerbault, P.; Lau, W.; Thomas, M.G.; Bradman, N.; Maniatis, N.; Swallow, D.M. World-wide distributions of lactase persistence alleles and the complex effects of recombination and selection. Hum. Genet. 2017, 136, 1445-1453. [CrossRef] [PubMed]

138. Segurel, L.; Bon, C. On the evolution of lactase persistence in humans. Annu. Rev. Genom. Hum. Genet. 2017, 18, 297-319. [CrossRef] [PubMed]

139. Luca, F.; Perry, G.H.; Rienzo, A.D. Evolutionary adaptations to dietary changes. Annu. Rev. Nutr. 2010, 30, 291-314. [CrossRef] [PubMed]

140. Kapheim, K.M.; Pan, H.; Li, C.; Salzberg, S.L.; Puiu, D.; Magoc, T.; Robertson, H.M.; Hudson, M.E.; Venkat, A.; Fischman, B.J.; et al. Social evolution. Genomic signatures of evolutionary transitions from solitary to group living. Science 2015, 348, 1139-1143. [CrossRef] [PubMed]

141. Shell, W.A.; Rehan, S.M. Behavioral and genetic mechanisms of social evolution: Insights from incipiently and facultatively social bees. Apidologie 2018, 49, 13-30. [CrossRef]

142. Rehan, S.M.; Berens, A.J.; Toth, A.L. At the brink of eusociality: Transcriptomic correlates of worker behaviour in a small carpenter bee. BMC Evol. Biol. 2014, 14, 260. [CrossRef]

143. Cande, J.; Prud'homme, B.; Gompel, N. Smells like evolution: The role of chemoreceptor evolution in behavioral change. Curr. Opin. Neurobiol. 2013, 23, 152-158. [CrossRef] 
144. Kreher, S.A.; Mathew, D.; Kim, J.; Carlson, J.R. Translation of sensory input into behavioral output via an olfactory system. Neuron 2008, 59, 110-124. [CrossRef]

145. Avila, F.W.; Mattei, A.L.; Wolfner, M.F. Sex peptide receptor is required for the release of stored sperm by mated Drosophila melanogaster females. J. Insect Physiol. 2015, 76, 1-6. [CrossRef]

146. Oldroyd, B.P.; Beekman, M. Effects of selection for honey bee worker reproduction on foraging traits. PLoS Biol. 2008, 6, e56. [CrossRef] [PubMed]

147. Marinissen, M.J.; Gutkind, J.S. G-protein-coupled receptors and signaling networks: Emerging paradigms. Trends Pharmacol. Sci. 2001, 22, 368-376. [CrossRef]

148. Simola, D.F.; Wissler, L.; Donahue, G.; Waterhouse, R.M.; Helmkampf, M.; Roux, J.; Nygaard, S.; Glastad, K.M.; Hagen, D.E.; Viljakainen, L.; et al. Social insect genomes exhibit dramatic evolution in gene composition and regulation while preserving regulatory features linked to sociality. Genome Res. 2013, 23, 1235-1247. [CrossRef] [PubMed]

149. Cooperband, M.F.; Cossé, A.A.; Jones, T.H.; Carrillo, D.; Cleary, K.; Canlas, I.; Stouthamer, R. Pheromones of three ambrosia beetles in the Euwallacea fornicatus species complex: Ratios and preferences. PeerJ 2017, 5, e3957. [CrossRef] [PubMed]

150. Beroza, M. Chemicals Controlling Insect Behavior; Elsevier Science: Amsterdam, The Netherlands, 2012.

151. Funaro, C.F.; Böröczky, K.; Vargo, E.L.; Schal, C. Identification of a queen and king recognition pheromone in the subterranean termite Reticulitermes flavipes. Proc. Natl. Acad. Sci. USA 2018, 115, 3888-3893. [CrossRef] [PubMed]

152. Yanay, C.; Morpurgo, N.; Linial, M. Evolution of insect proteomes: Insights into synapse organization and synaptic vesicle life cycle. Genome Biol. 2008, 9, R27. [CrossRef] [PubMed]

153. Spangler, S.A.; Hoogenraad, C.C. Liprin-alpha proteins: Scaffold molecules for synapse maturation. Biochem. Soc. Trans. 2007, 35, 1278-1282. [CrossRef]

154. Beaubien, F.; Raja, R.; Kennedy, T.E.; Fournier, A.E.; Cloutier, J.-F. Slitrk1 is localized to excitatory synapses and promotes their development. Sci. Rep. 2016, 6, 27343. [CrossRef]

155. Garbe, J.C.; Yang, E.; Fristrom, J.W. Imp-12: An essential secreted immunoglobulin family member implicated in neural and ectodermal development in Drosophila. Development 1993, 119, 1237-1250.

156. Lichte, B.; Veh, R.W.; Meyer, H.E.; Kilimann, M.W. Amphiphysin, a novel protein associated with synaptic vesicles. EMBO J. 1992, 11, 2521-2530. [CrossRef]

157. Shi, L.; Quick, M.; Zhao, Y.; Weinstein, H.; Javitch, J.A. The mechanism of a neurotransmitter: Sodium symporter-inward release of $\mathrm{Na}+$ and substrate is triggered by substrate in a second binding site. Mol. Cell 2008, 30, 667-677. [CrossRef] [PubMed]

158. Goulding, S.E.; zur Lage, P.; Jarman, A.P. Amos, a proneural gene for Drosophila olfactory sense organs that is regulated by lozenge. Neuron 2000, 25, 69-78. [CrossRef]

159. Huang, M.-L.; Hsu, C.-H.; Chien, C.-T. The proneural gene amos promotes multiple dendritic neuron formation in the Drosophila peripheral nervous system. Neuron 2000, 25, 57-67. [CrossRef]

160. Schweisguth, F.; Posakony, J.W. Suppressor of hairless, the Drosophila homolog of the mouse recombination signal-binding protein gene, controls sensory organ cell fates. Cell 1992, 69, 1199-1212. [CrossRef]

161. Corthals, K.; Heukamp, A.S.; Kossen, R.; Grosshennig, I.; Hahn, N.; Gras, H.; Gopfert, M.C.; Heinrich, R.; Geurten, B.R.H. Neuroligins Nlg2 and Nlg4 affect social behavior in Drosophila melanogaster. Front. Psychiatry 2017, 8, 113. [CrossRef] [PubMed]

162. Bracewell, R.R.; Six, D.L. Broadscale specificity in a bark beetle-fungal symbiosis: A spatio-temporal analysis of the mycangial fungi of the western pine beetle. Microb. Ecol. 2014, 68, 859-870. [CrossRef] [PubMed]

163. Kostovcik, M.; Bateman, C.C.; Kolarik, M.; Stelinski, L.L.; Jordal, B.H.; Hulcr, J. The ambrosia symbiosis is specific in some species and promiscuous in others: Evidence from community pyrosequencing. ISME J. 2014, 9, 126. [CrossRef]

164. Six, D.L.; Bentz, B.J. Temperature determines symbiont abundance in a multipartite bark beetle-fungus ectosymbiosis. Microb. Ecol. 2007, 54, 112-118. [CrossRef]

165. Addison, A.L.; Powell, J.A.; Six, D.L.; Moore, M.; Bentz, B.J. The role of temperature variability in stabilizing the mountain pine beetle-fungus mutualism. J. Theor. Biol. 2013, 335, 40-50. [CrossRef]

166. Freeman, S.; Sharon, M.; Dori-Bachash, M.; Maymon, M.; Belausov, E.; Maoz, Y.; Margalit, O.; Protasov, A.; Mendel, Z. Symbiotic association of three fungal species throughout the life cycle of the ambrosia beetle Euwallacea nr. fornicatus. Symbiosis 2016, 68, 115-128. [CrossRef] 
167. Seybold, S.J.; Tittiger, C. Biochemistry and molecular biology of de novo isoprenoid pheromone production in the scolytidae. Annu. Rev. Entomol. 2003, 48, 425-453. [CrossRef] [PubMed]

168. Seybold, S.J.; Bohlmann, J.; Raffa, K.F. Biosynthesis of coniferophagous bark beetle pheromones and conifer isoprenoids: Evolutionary perspective and synthesis. Can. Entomol. 2012, 132, 697-753. [CrossRef]

169. Blomquist, G.J.; Figueroa-Teran, R.; Aw, M.; Song, M.; Gorzalski, A.; Abbott, N.L.; Chang, E.; Tittiger, C. Pheromone production in bark beetles. Insect Biochem. Mol. Biol. 2010, 40, 699-712. [CrossRef] [PubMed]

170. Kashiwagi, T.; Nakashima, T.; Tebayashi, S.-I.; Kim, C.-S. Determination of the absolute configuration of quercivorol, (1S, 4R)-p-menth-2-en-1-ol, an aggregation pheromone of the ambrosia beetle Platypus quercivorus (Coleoptera: Platypodidae). Biosci. Biotechnol. Biochem. 2006, 70, 2544-2546. [CrossRef] [PubMed]

(C) 2018 by the authors. Licensee MDPI, Basel, Switzerland. This article is an open access article distributed under the terms and conditions of the Creative Commons Attribution (CC BY) license (http:/ / creativecommons.org/licenses/by/4.0/). 